\title{
MINERALOGY OF PETRIFIED TREES IN THE PETRIFIED FOREST PARK, TAK PROVINCE, THAILAND
}

\section{Associate Prof. Dr. Seriwat Saminpanya}

Department of General Science, Faculty of Science, Srinakharinwirot

University, 114 Sukhumvit 23,

Watthana, Bangkok, 10110, Thailand

In session number 271 Paper No. 271-7, titled "D4. Geochemistry," Presentation Time: 3:15 PM

GSA Annual Meeting in Indianapolis, Indiana, USA - 2018

\section{Srinakharinwirot University}

Thailand 


\section{Layout of presentation:}

1) Introduction

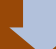

2) Location, Materials, and Methods

3) Results

4) Summary of

Results

5) Discussion and Interpretation 


\section{1) Introduction}

- 7 petrified trees in the Petrified Forest Park, Tak Province in Northern Thailand were investigated in terms of mineralogy.

- The petrified tree No. 1 (BT1) is said to be the longest one in the world, (69 meters).

- The trees fell down and were buried in the Quaternary palaeoriver gravel beds at the depth $<10 \mathrm{~m}$.

- Later, the overburden was removed and now they are exposed to an open atmosphere. 


\section{Why do we study the minerals of petrified trees in this site?}

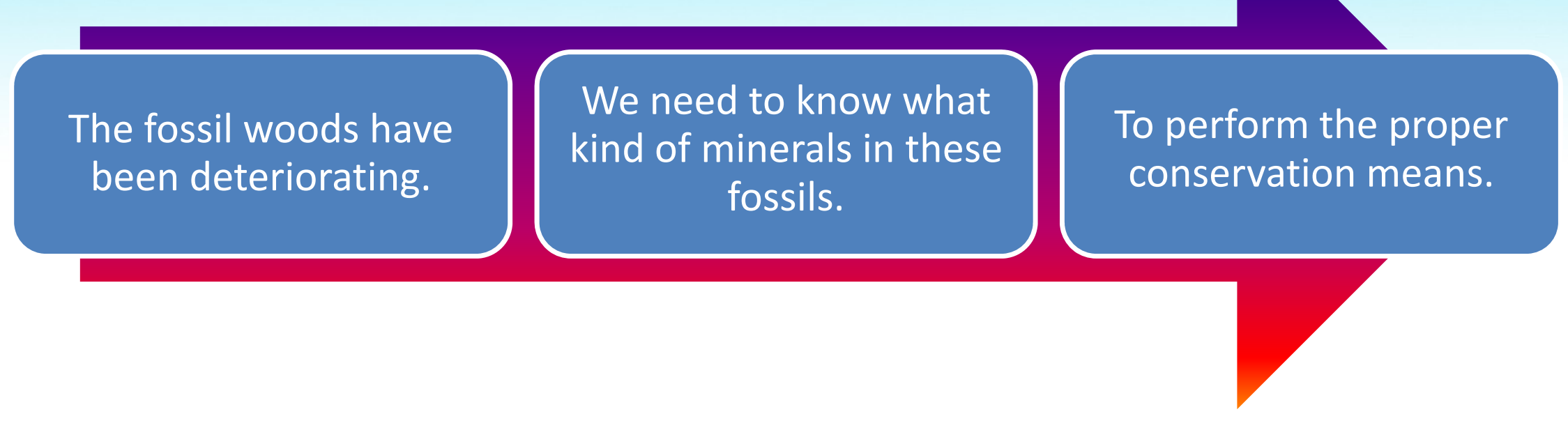




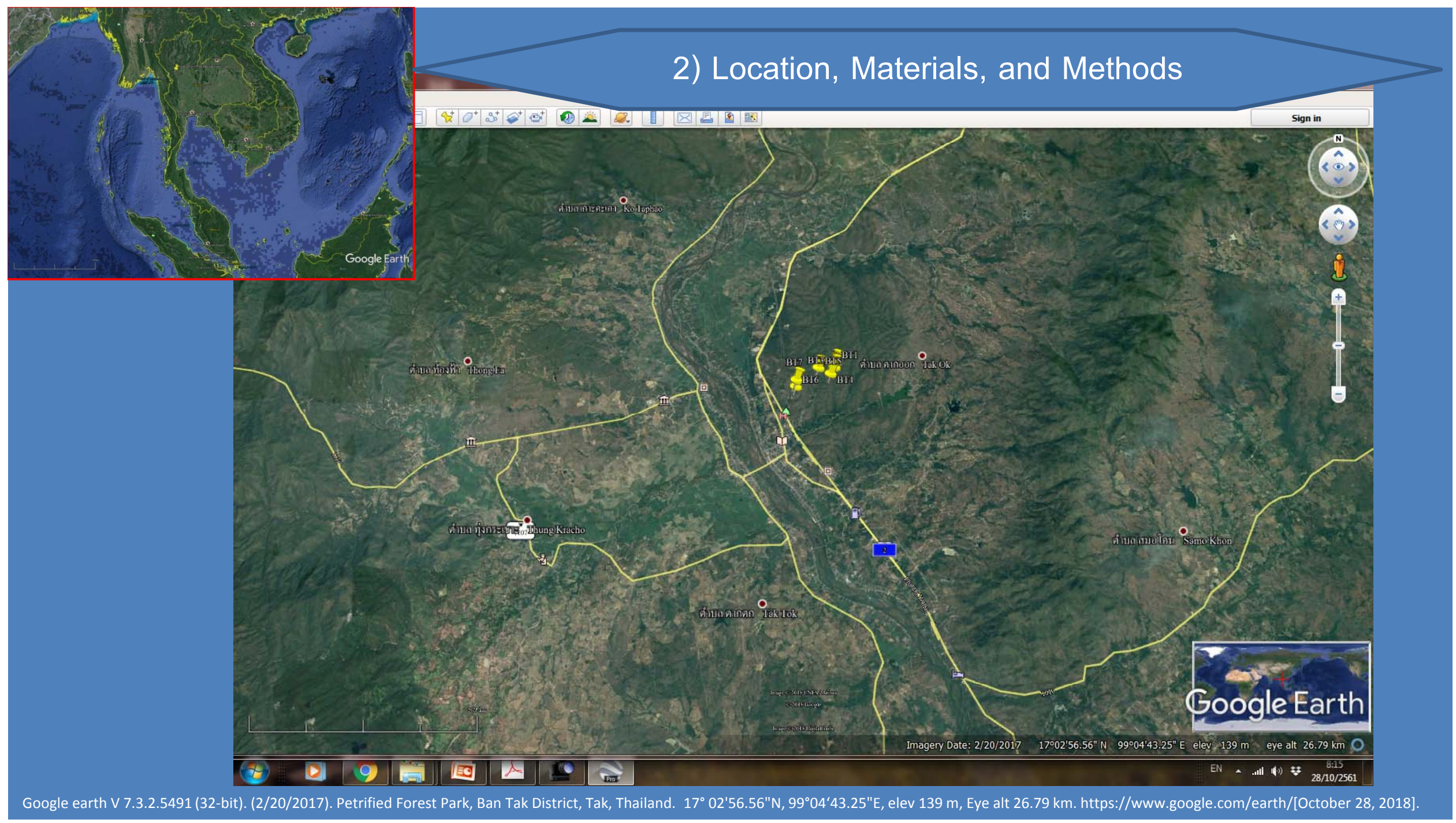




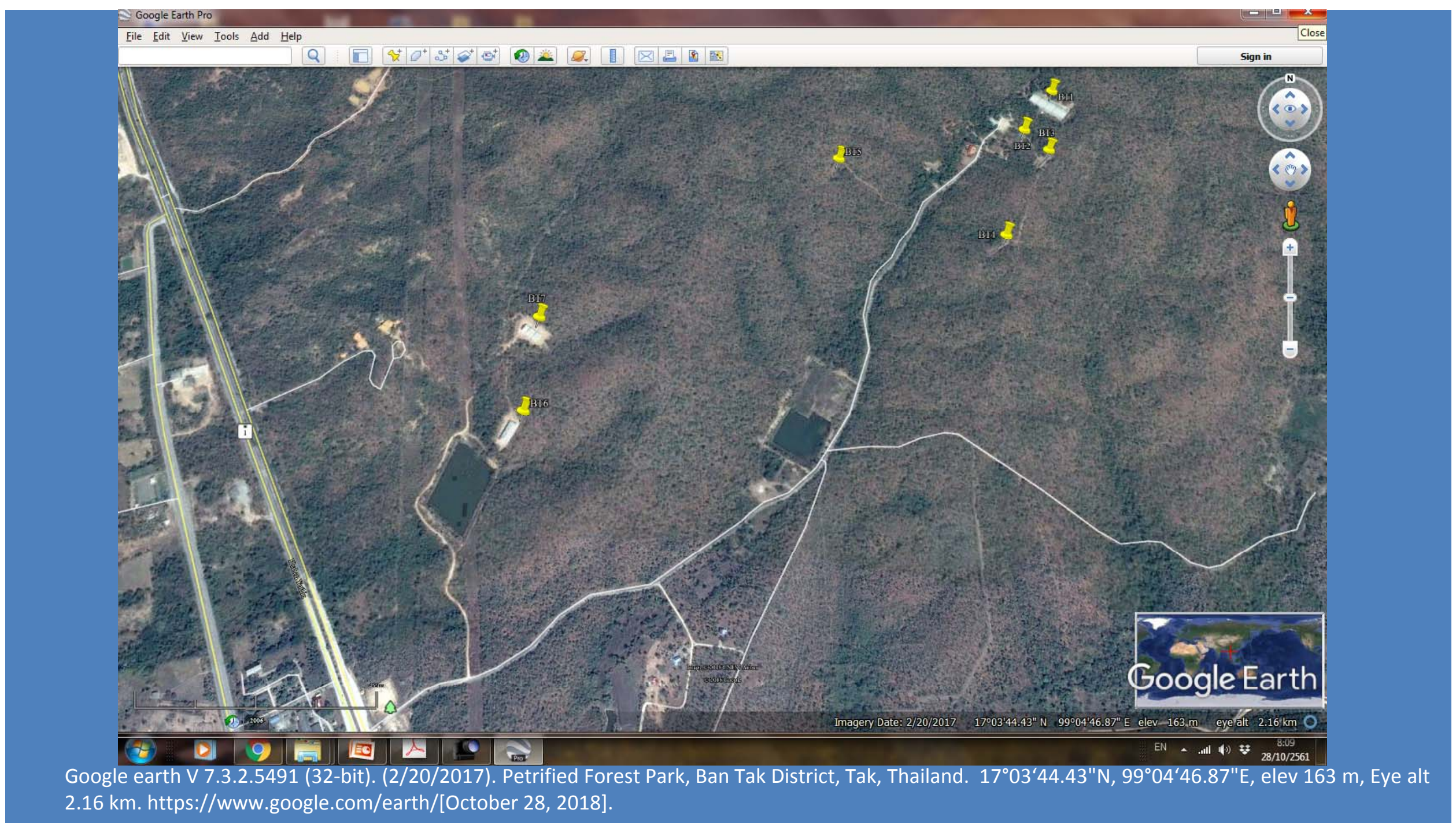




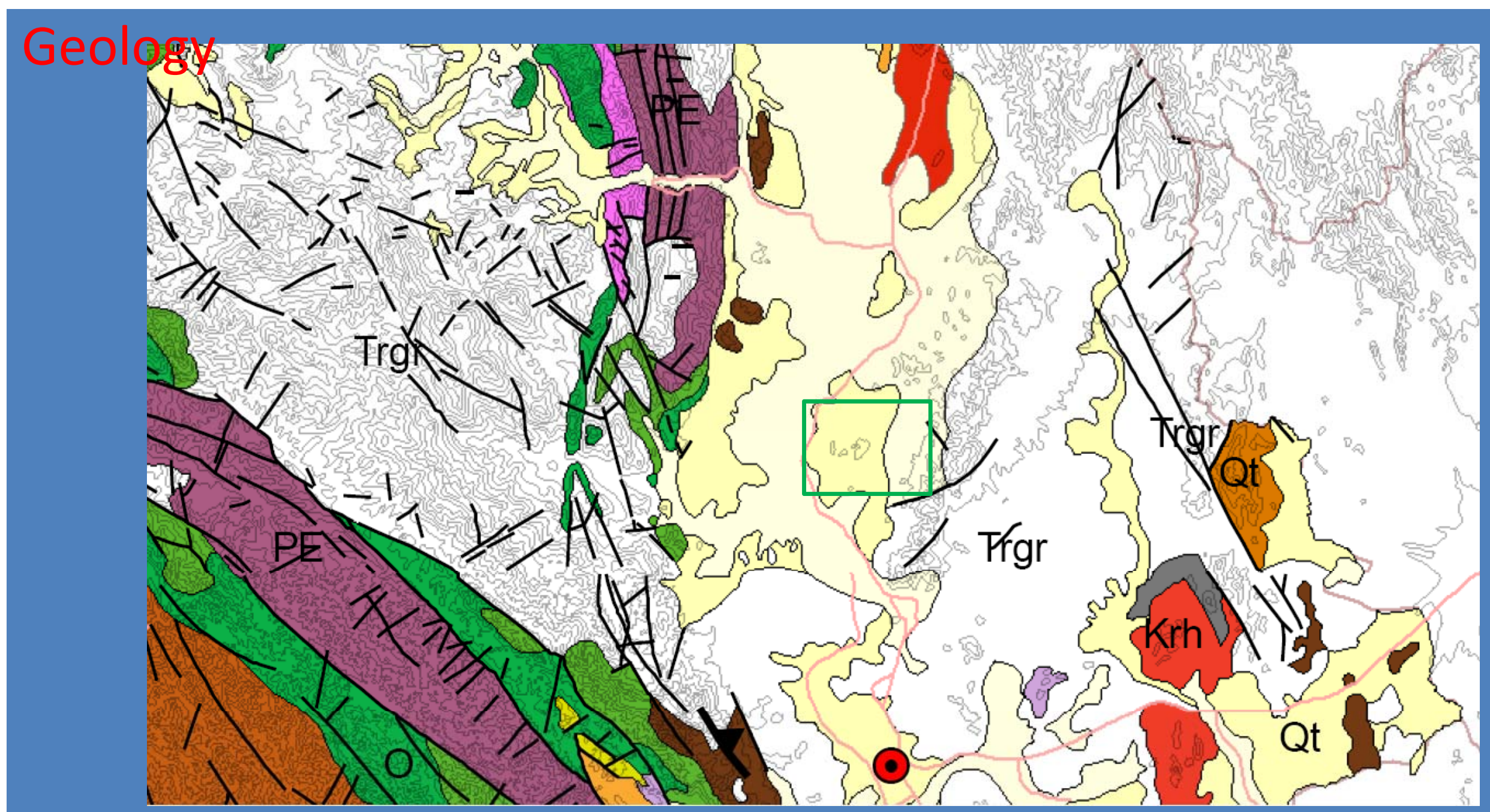

Department of Mineral Resources, 2007. Geological map of Tak province, Thailand [http://www.dmr.go.th/n_more_news.php?nid=79590]. 


\begin{tabular}{|c|c|c|c|}
\hline Tree No. & Species & Length (m.) & Width (m.) \\
\hline BT1 & Koompassioxylon elegans & 72.2 (now 69) & 1.8 \\
\hline BT2 & Pahudioxylon cf. sahnii & 31.3 & 0.5 \\
\hline BT3 & Koompassioxylon elegans & 32.4 & 2.1 \\
\hline BT4 & Koompassioxylon elegans & 44.2 & 1.4 \\
\hline BT5 & Pahudioxylon cf. sahnii & 22.2 & 1.2 \\
\hline BT6 & Koompassioxylon elegans & 34.5 & 1.55 \\
\hline BT7 & Koompassioxylon elegans & 38.7 & 1.5 \\
\hline
\end{tabular}




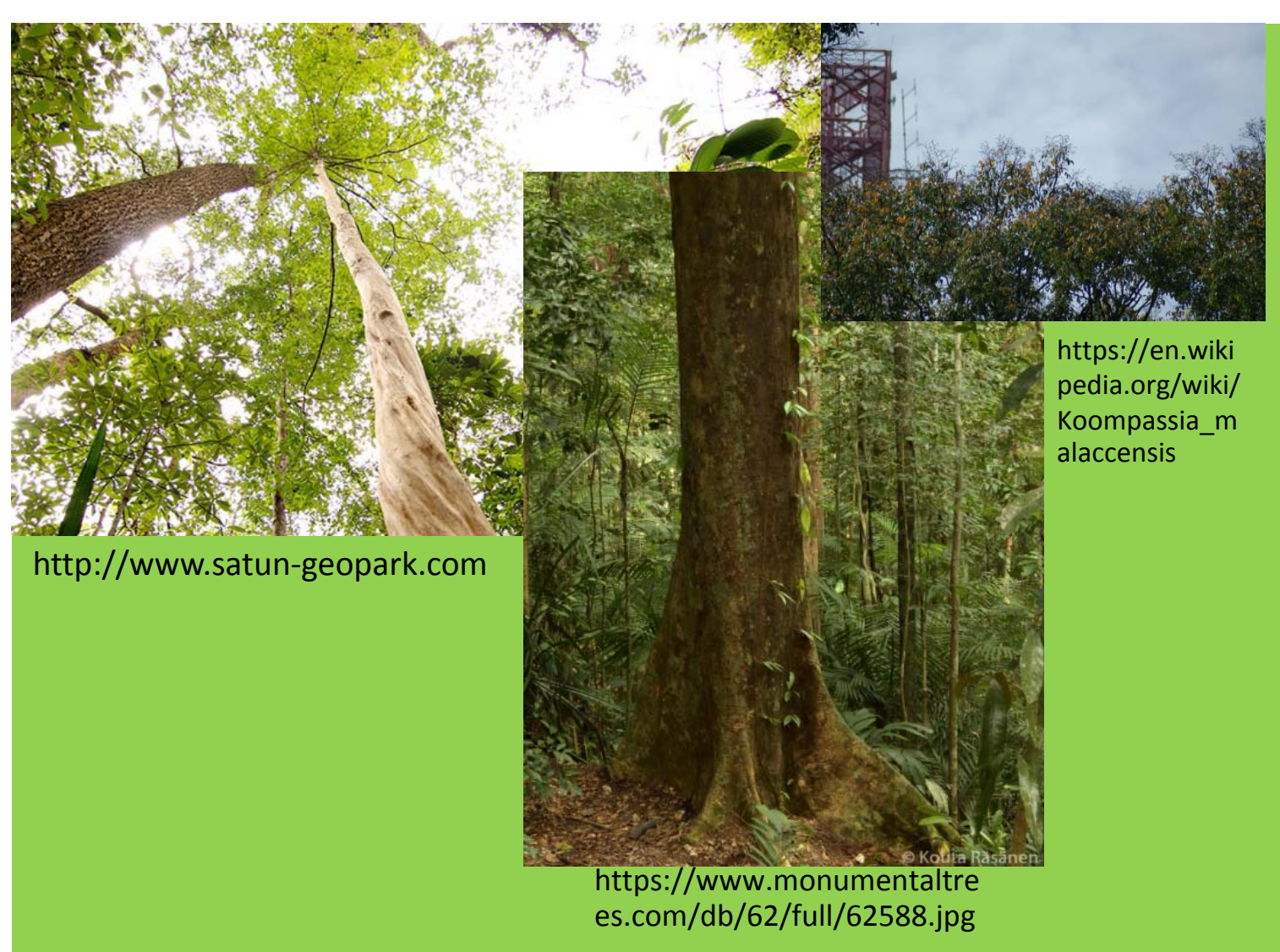

Koompassioxylon elegans, "Thong-Berng", currently found around the border of Thailand near Malaysia, and in Borneo and Indonesia.

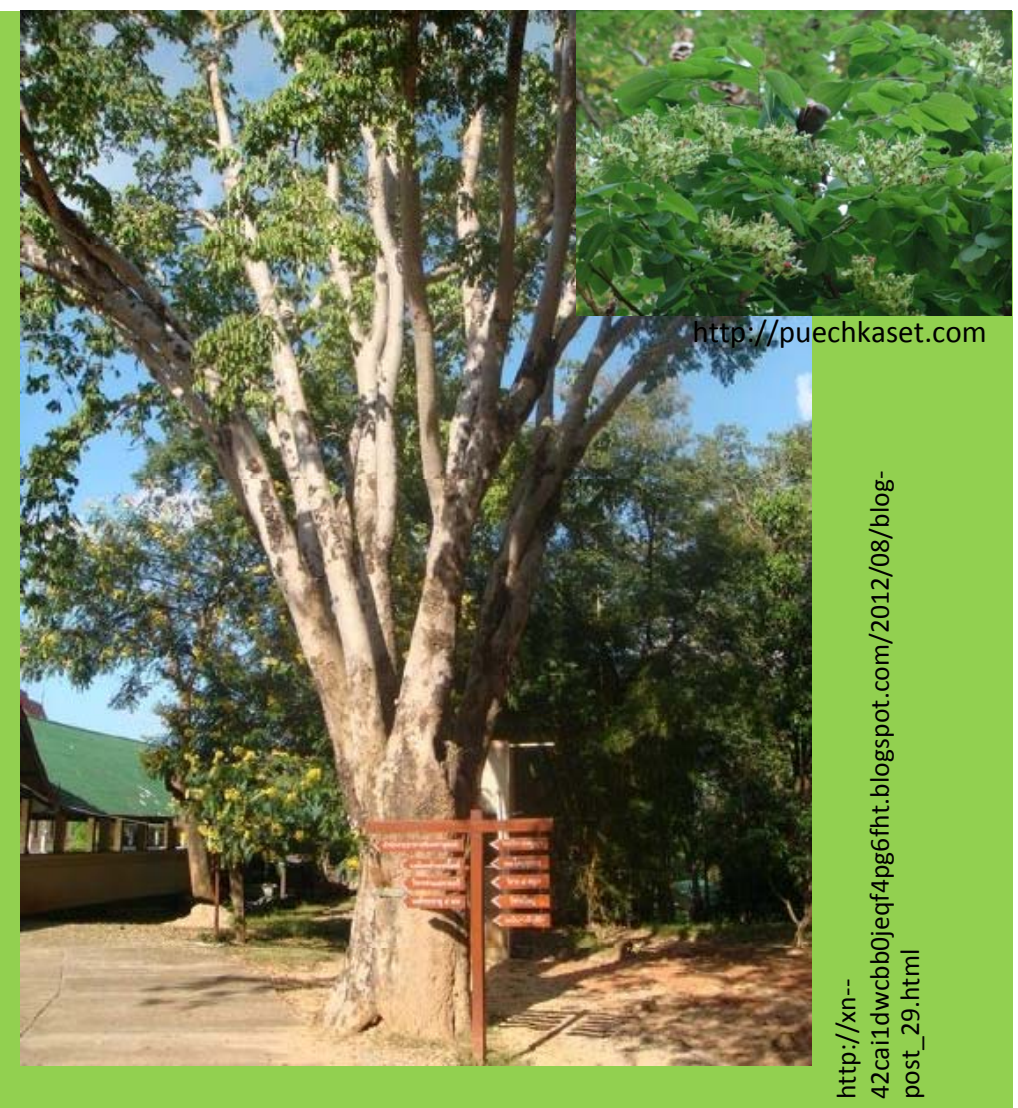

Pahudioxylon cf. sahnii, "Ma-Ca-Mong", currently found in the deciduous and dipterocarp forests in Thailand, Laos, Cambodia, and Vietnam. 


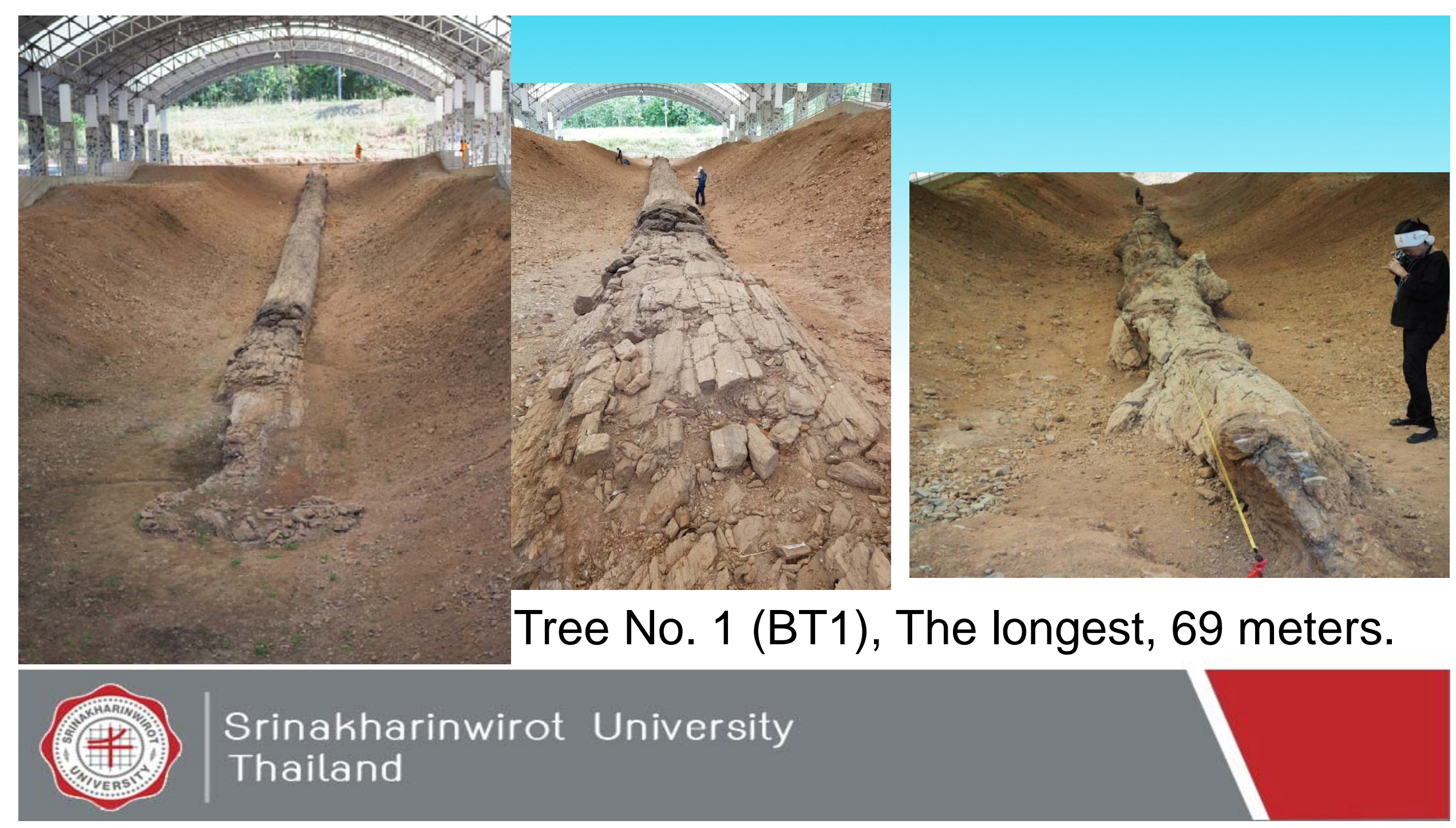




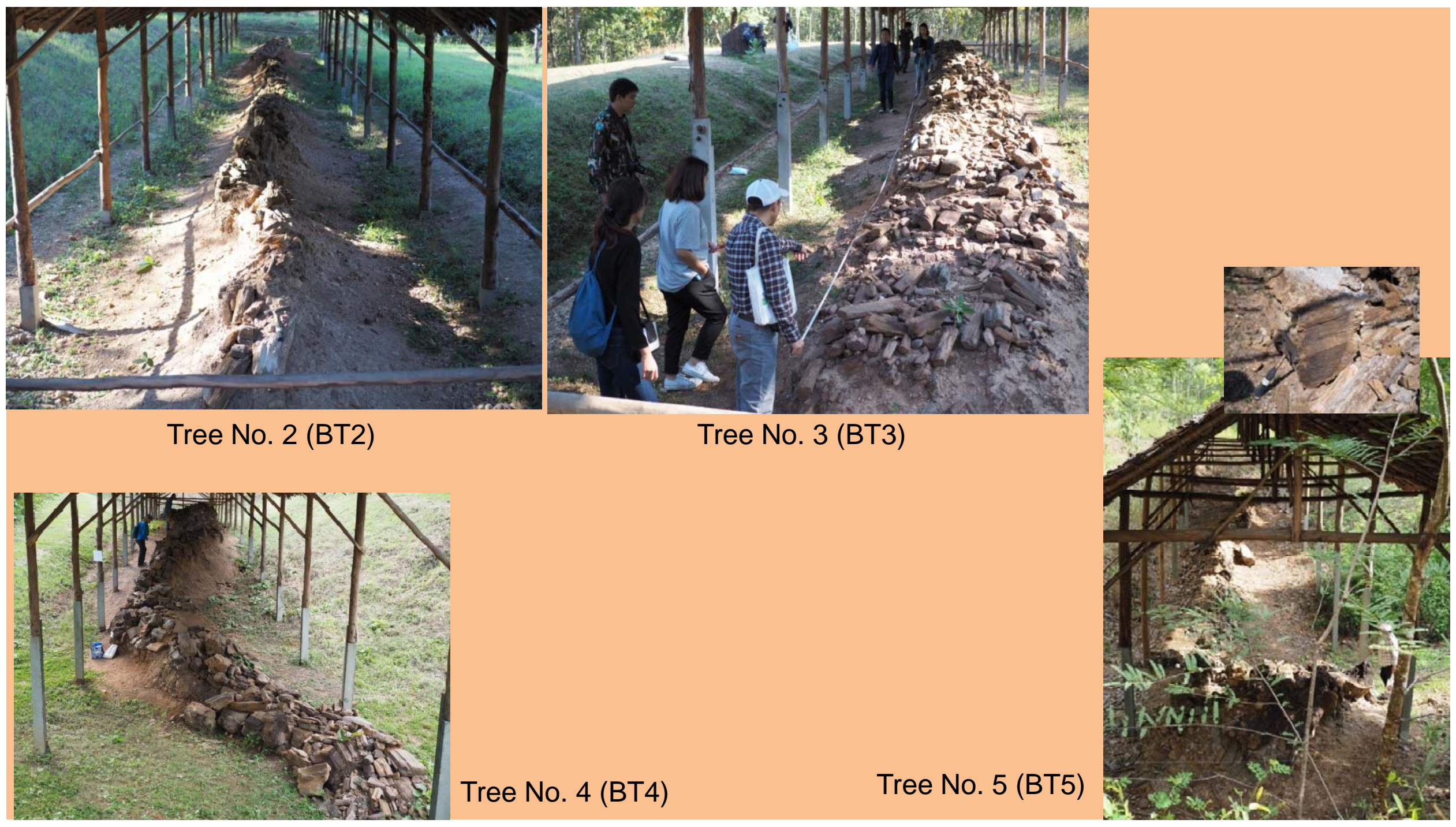




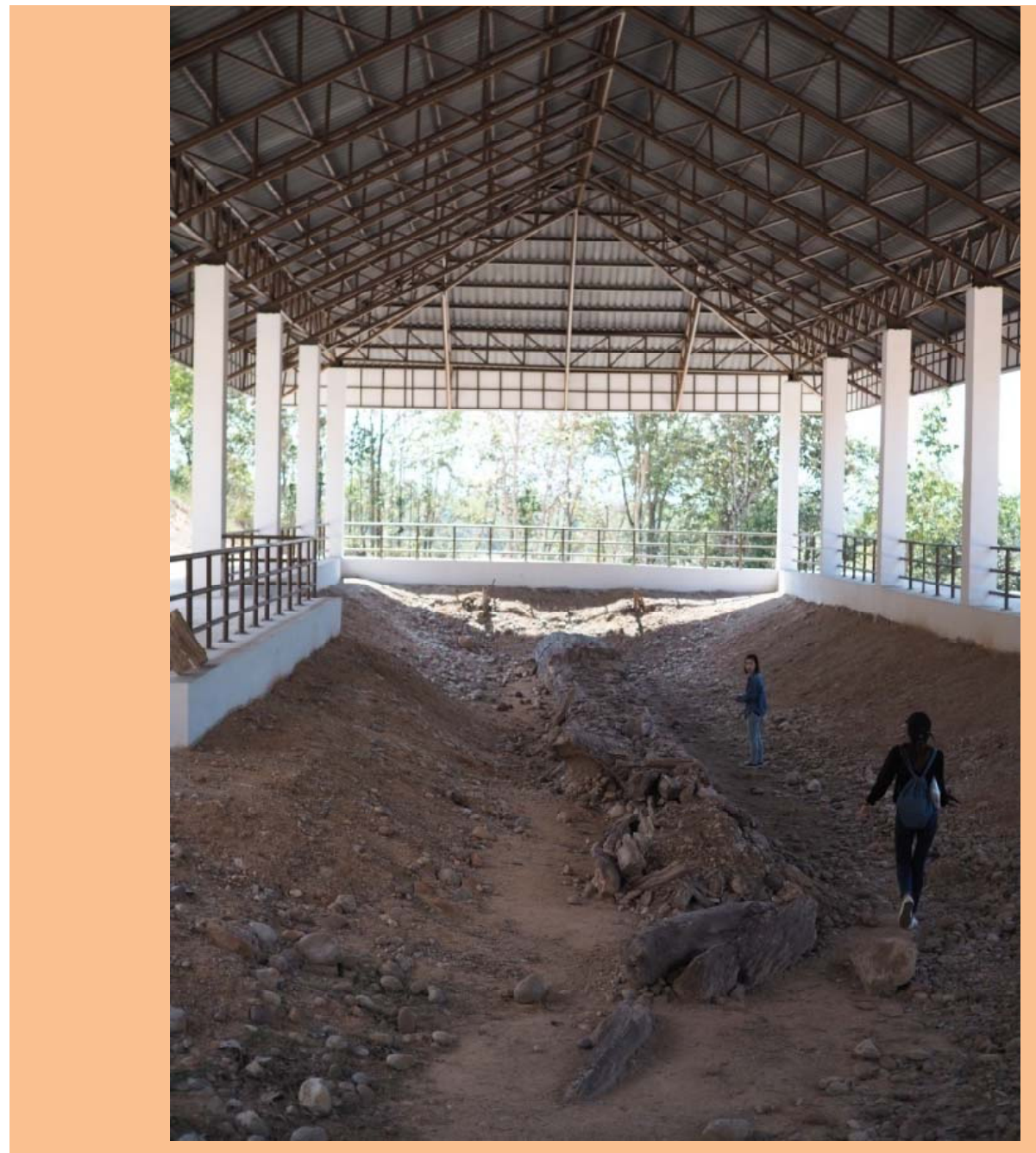

Tree No. 6 (BT6)

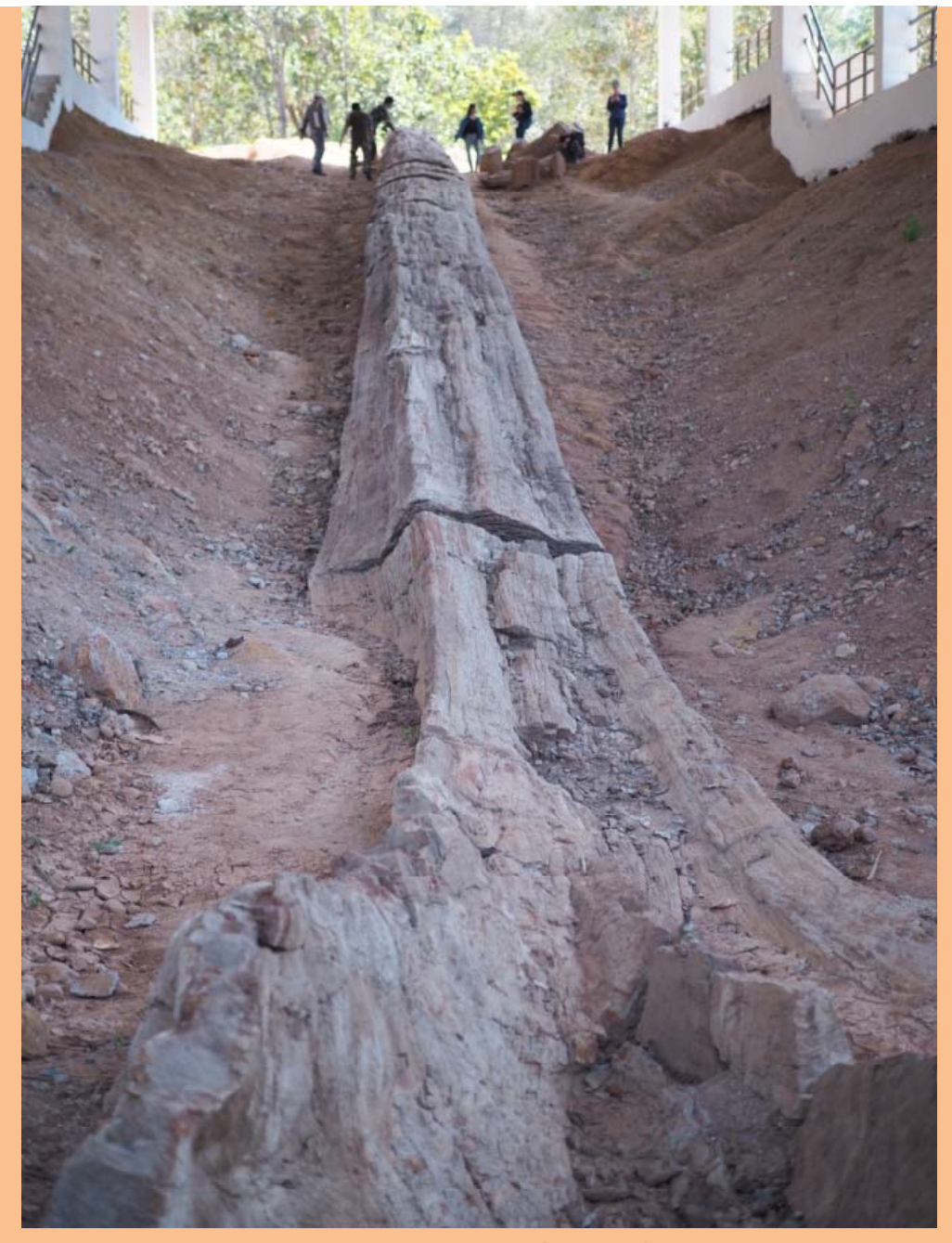

Tree No. 7 (BT7) 


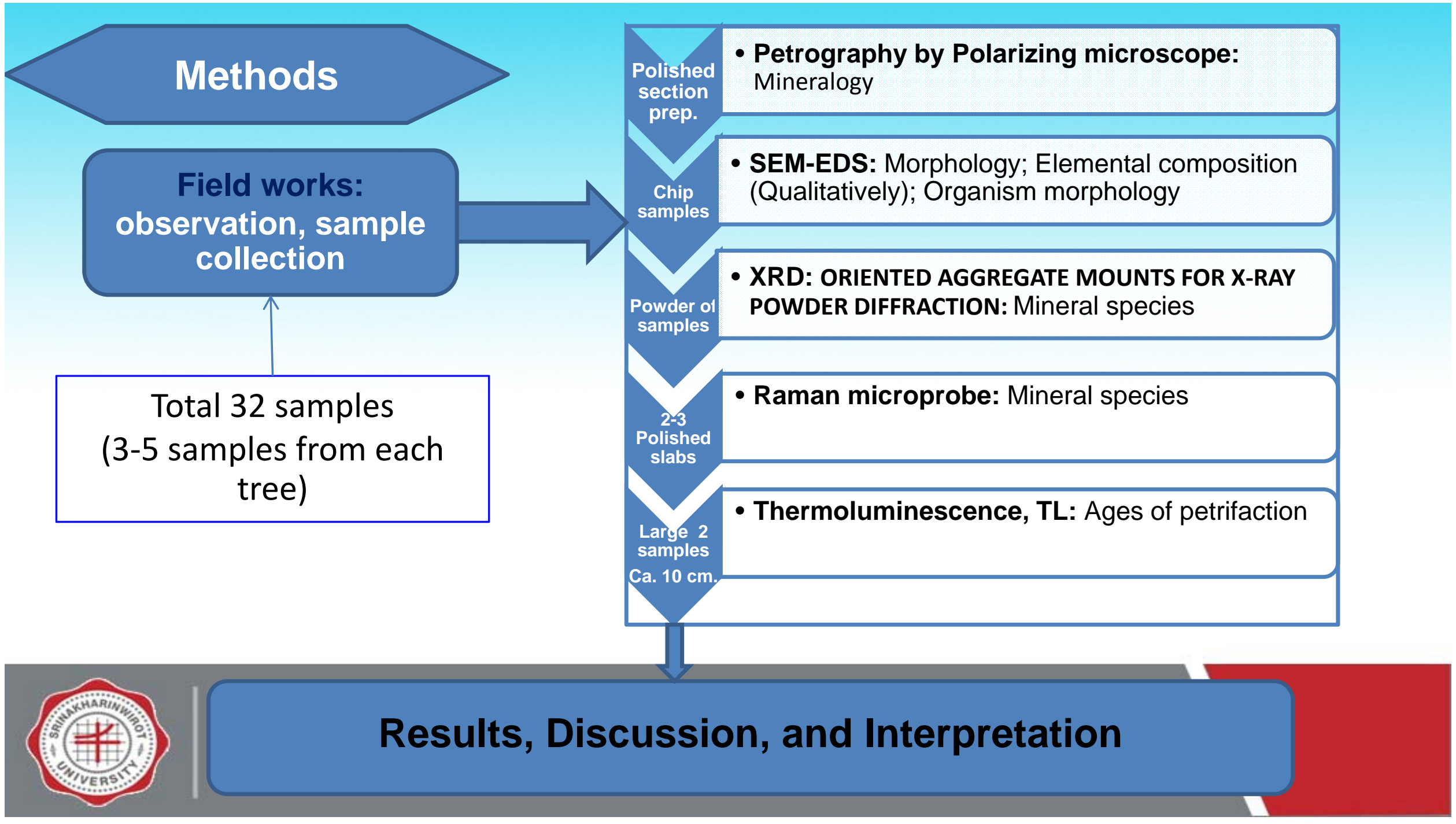




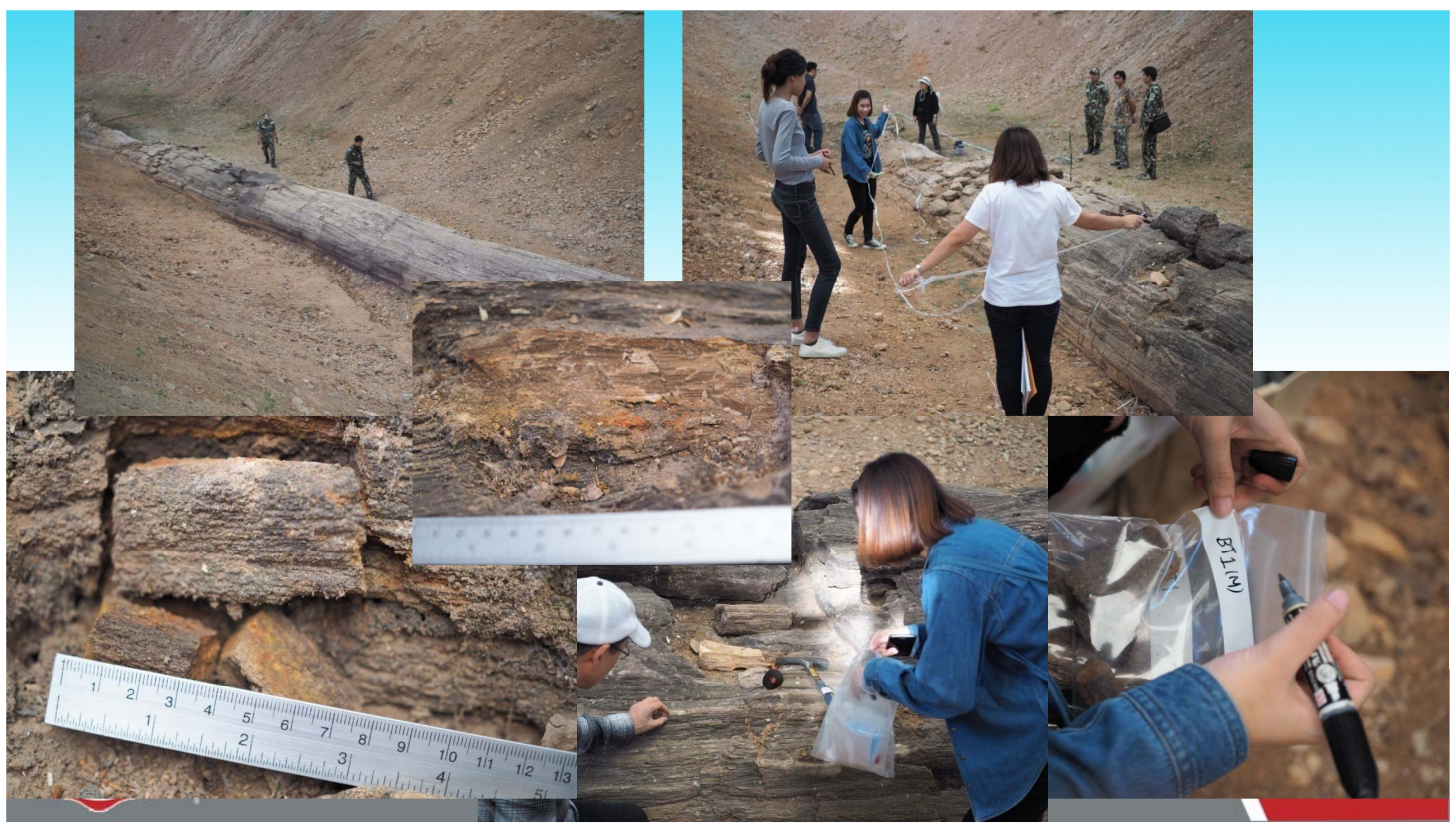




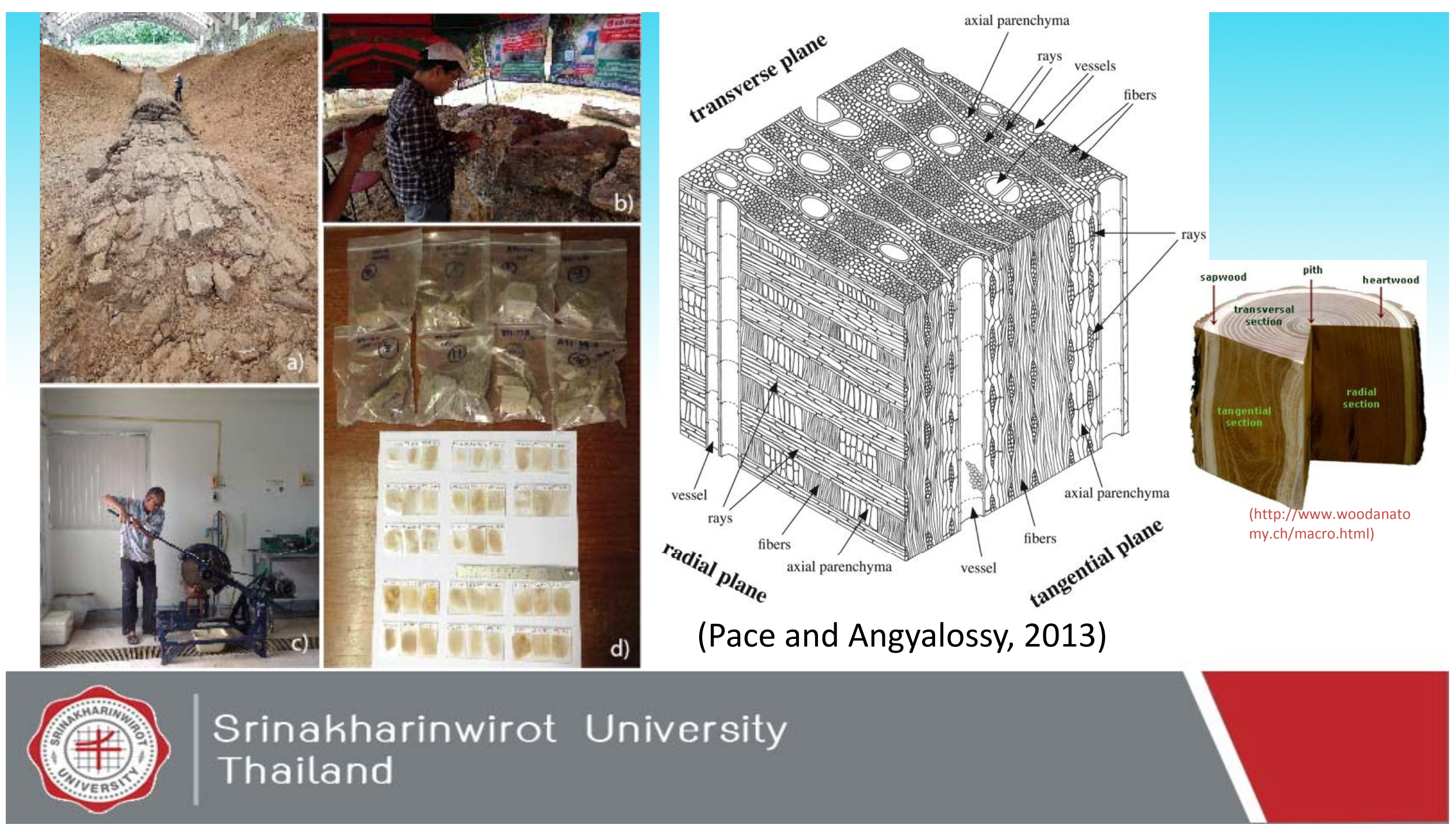




\section{4tos is ธอง.550}
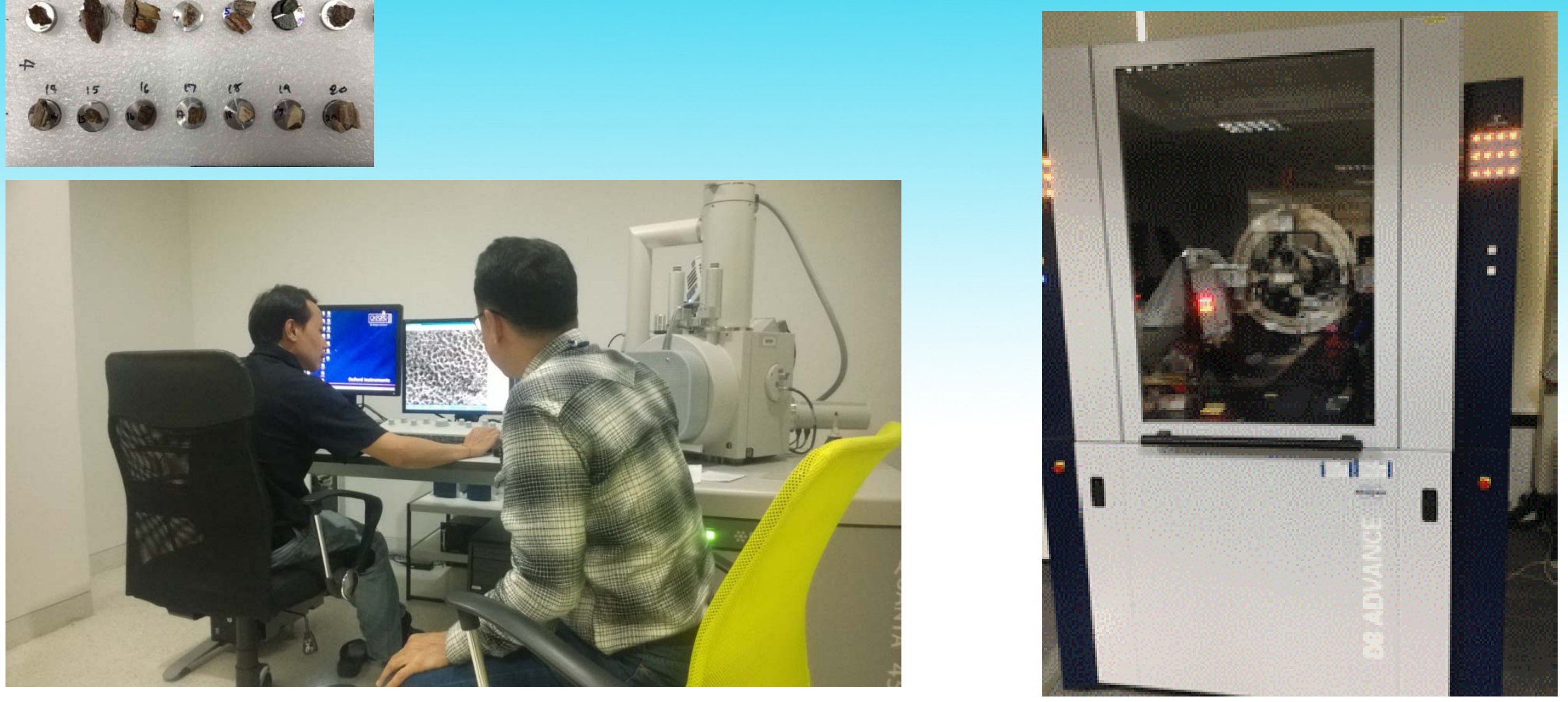

Srinakharinwirot University Thailand

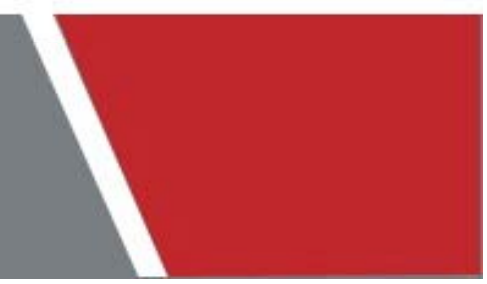




\section{3) Results}

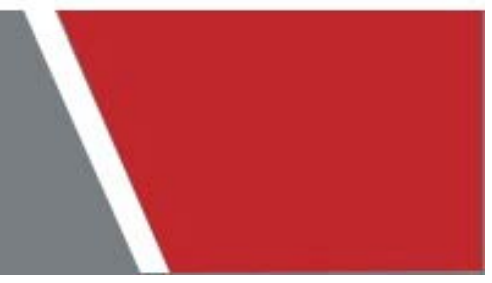



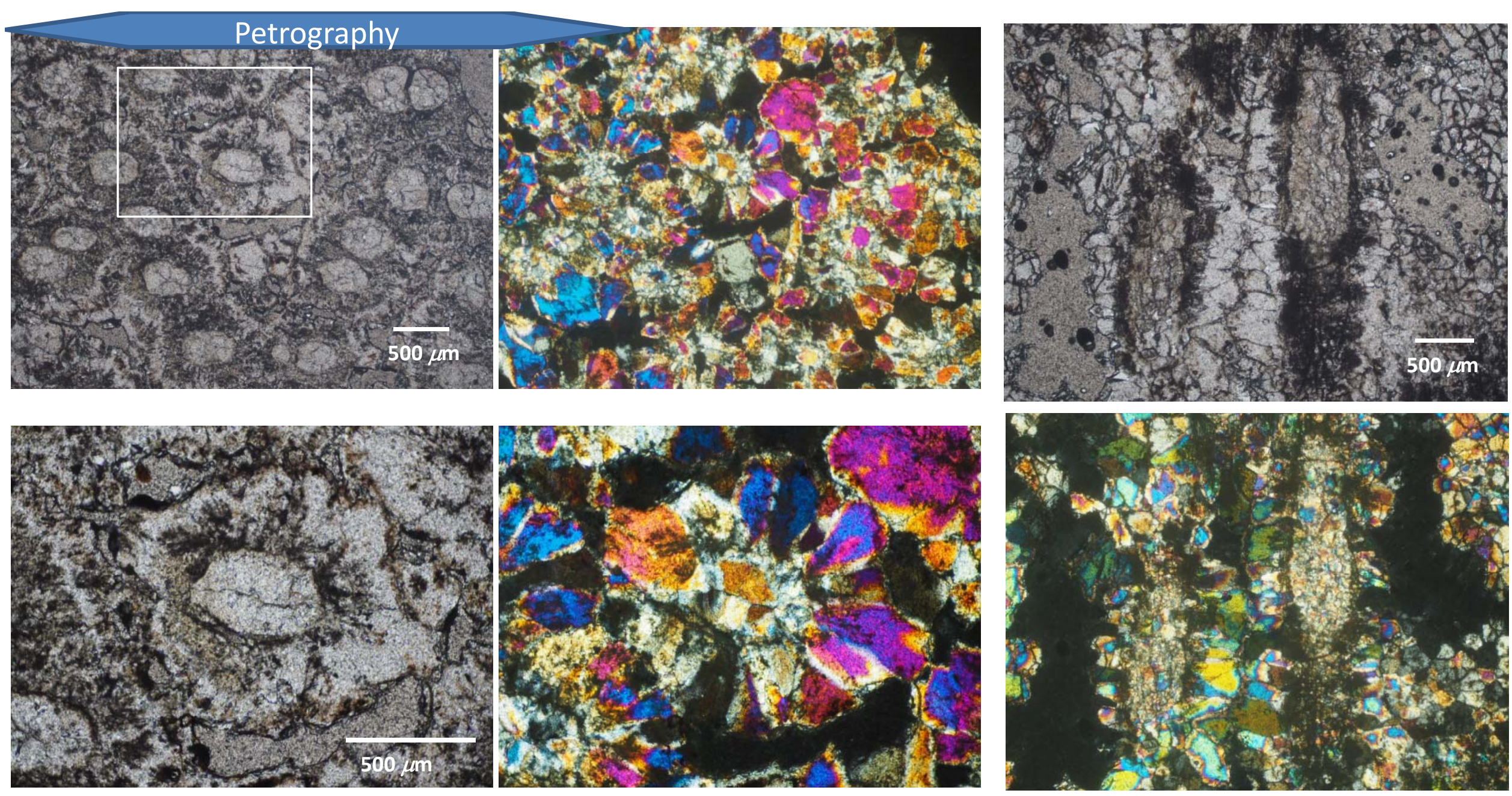

BT1-11.97(C)

BT1-11.97(R) 

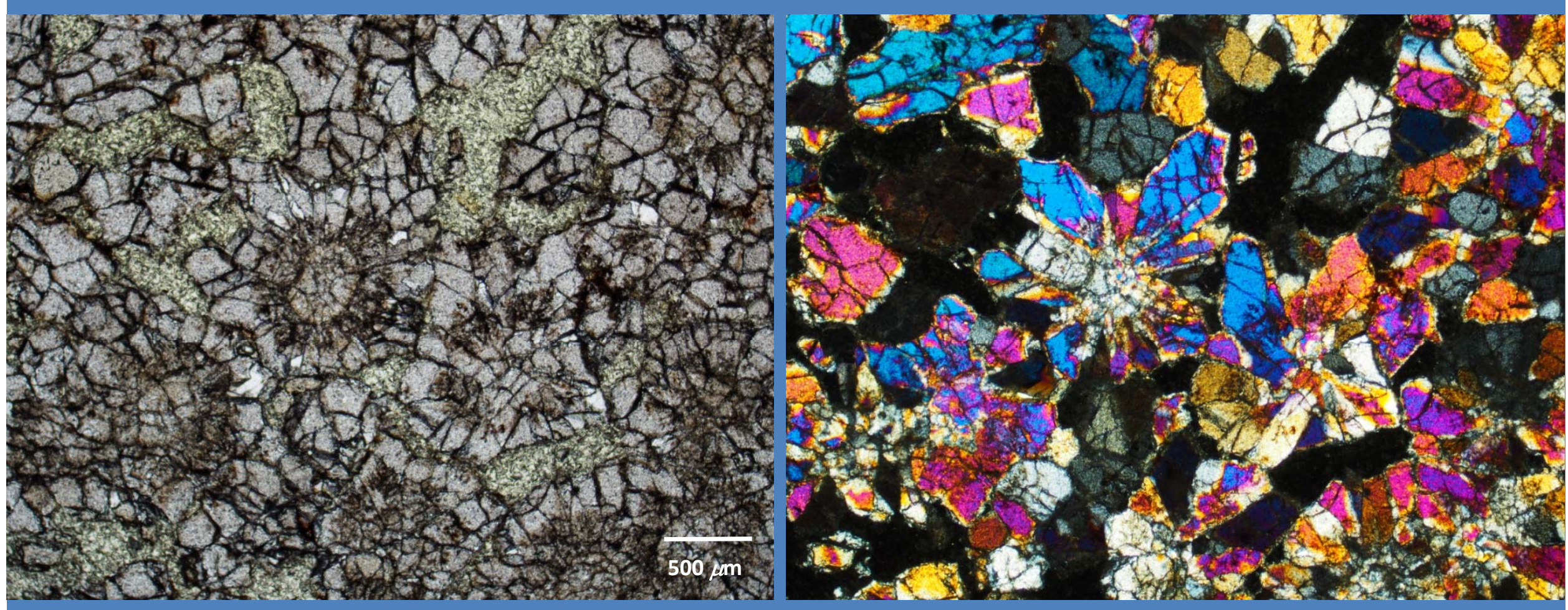

$$
\text { BT1-18.5(C) }
$$



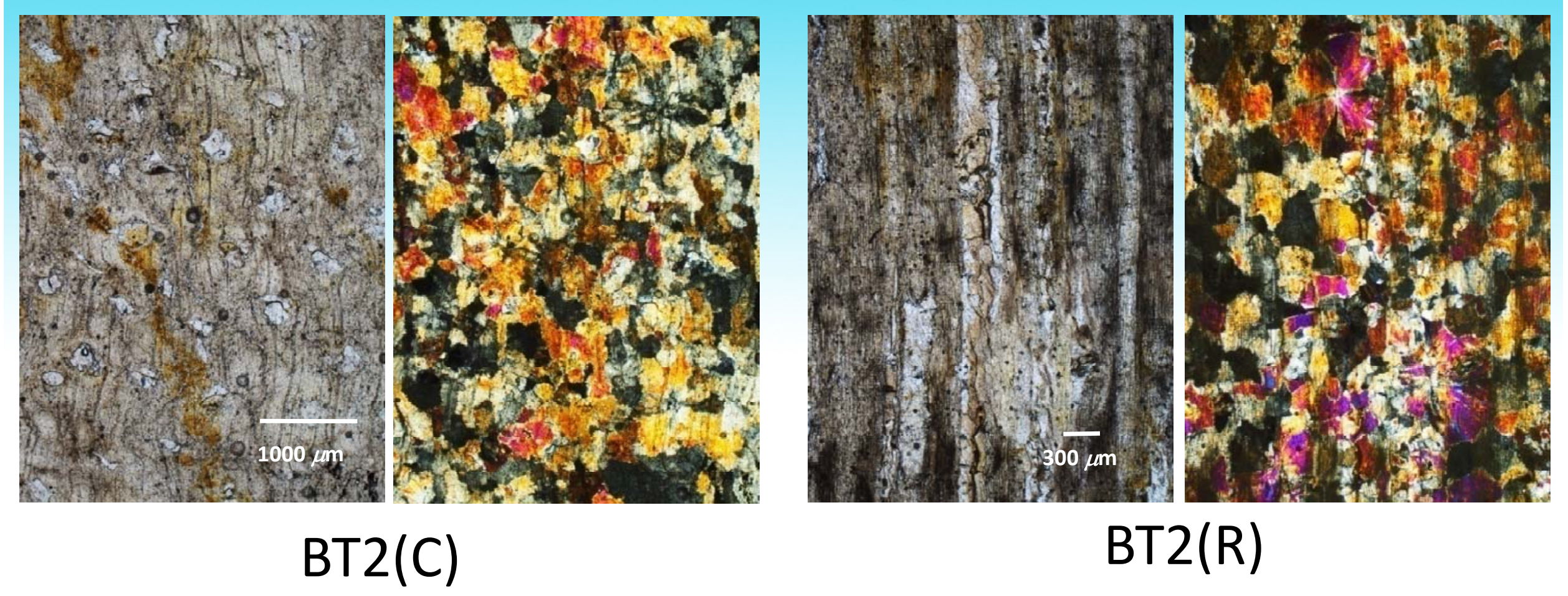

\begin{tabular}{l|l} 
Srinakharinwirot University \\
Thailand
\end{tabular}

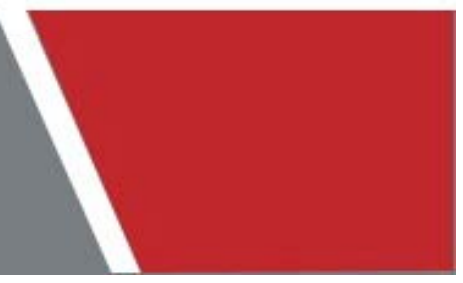




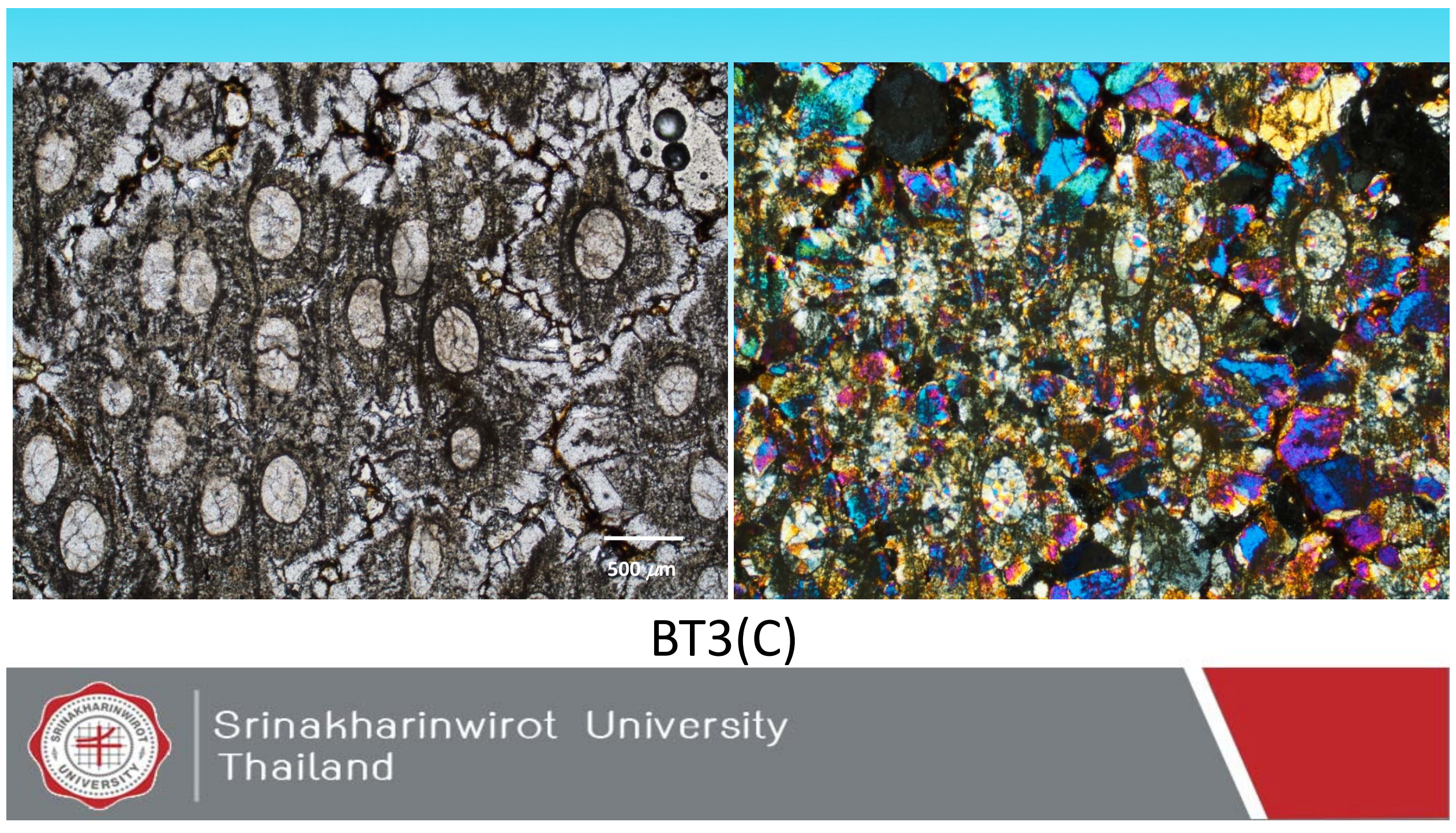




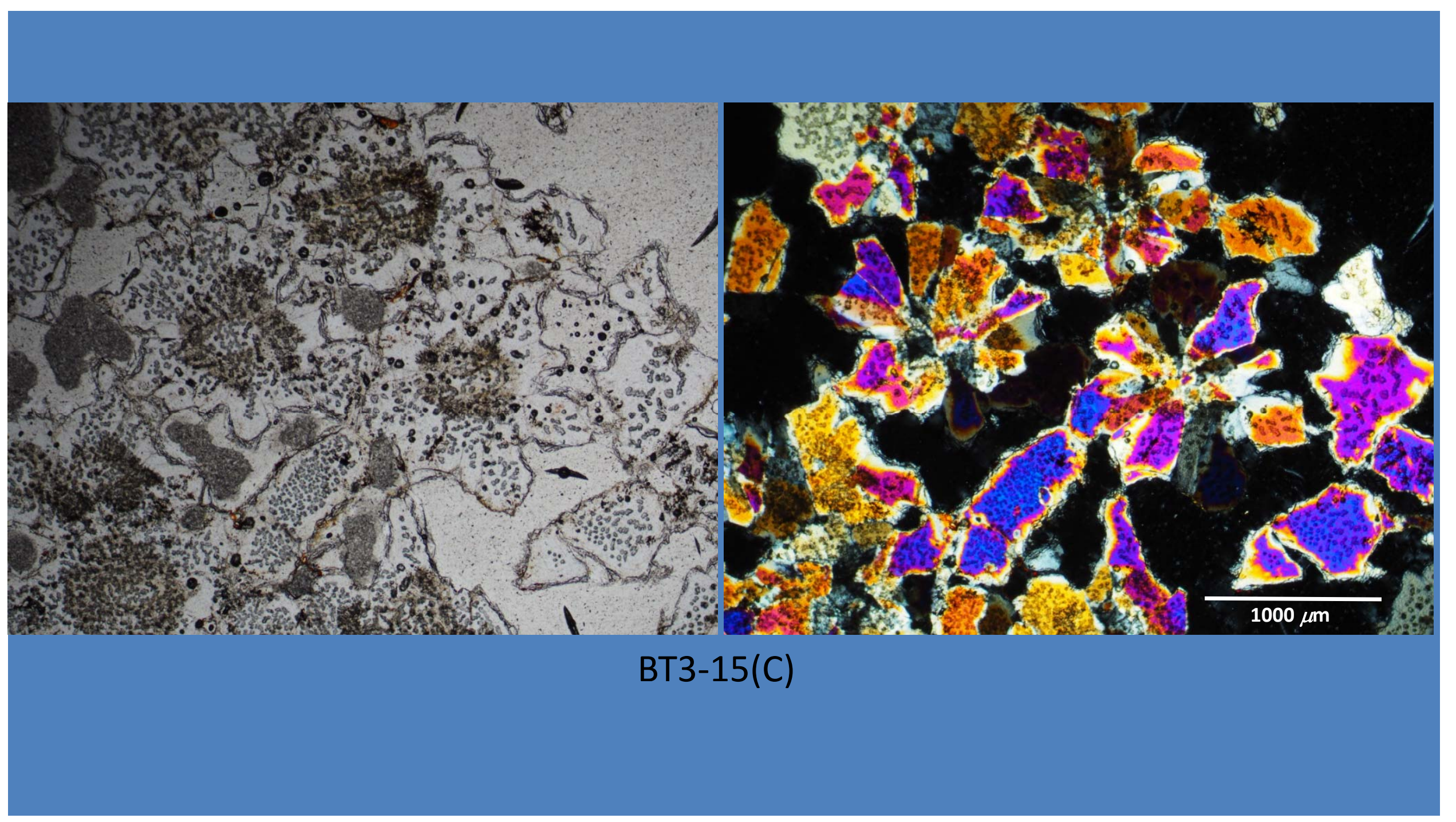



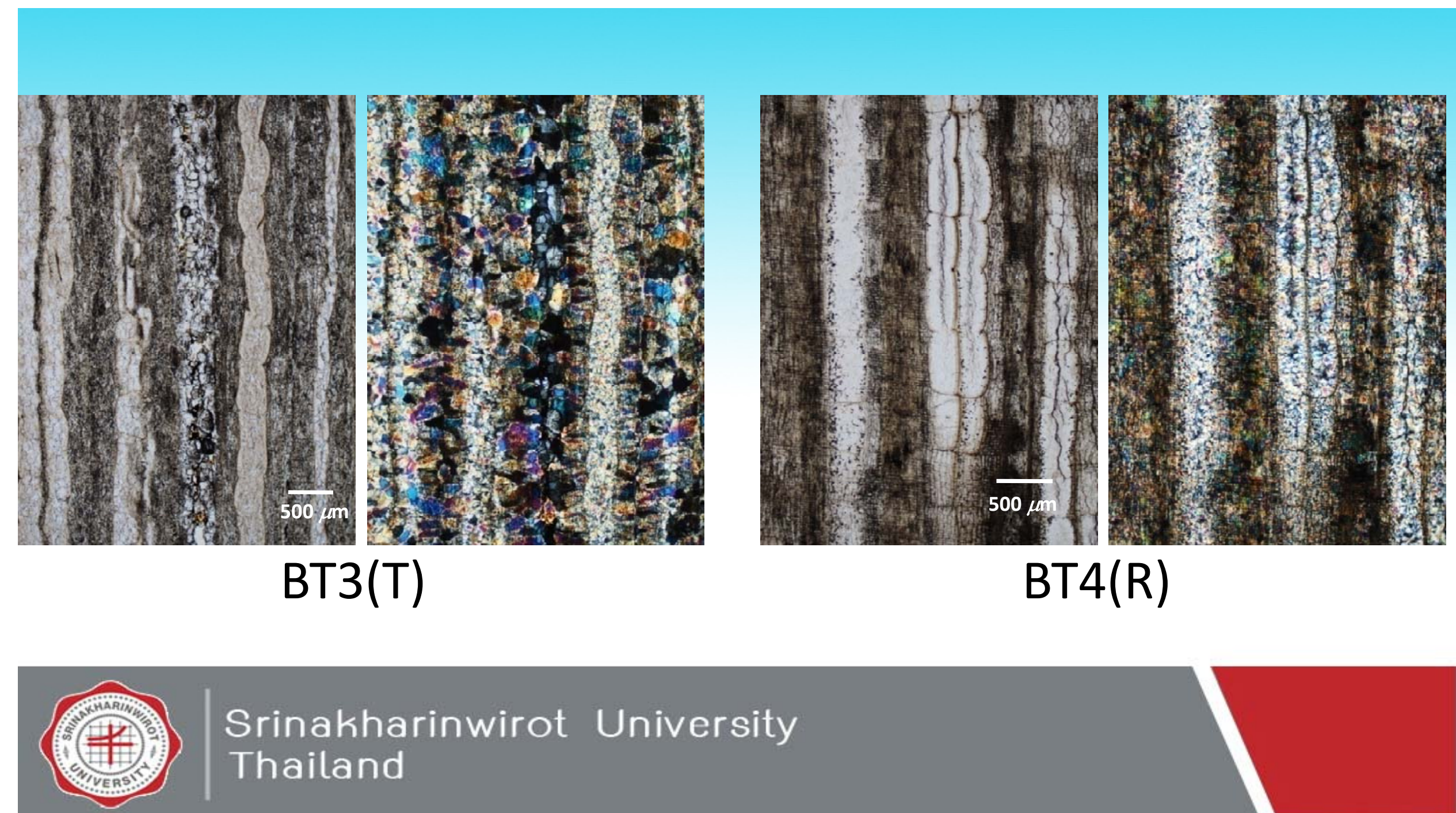

Srinakharinwirot University Thailand 

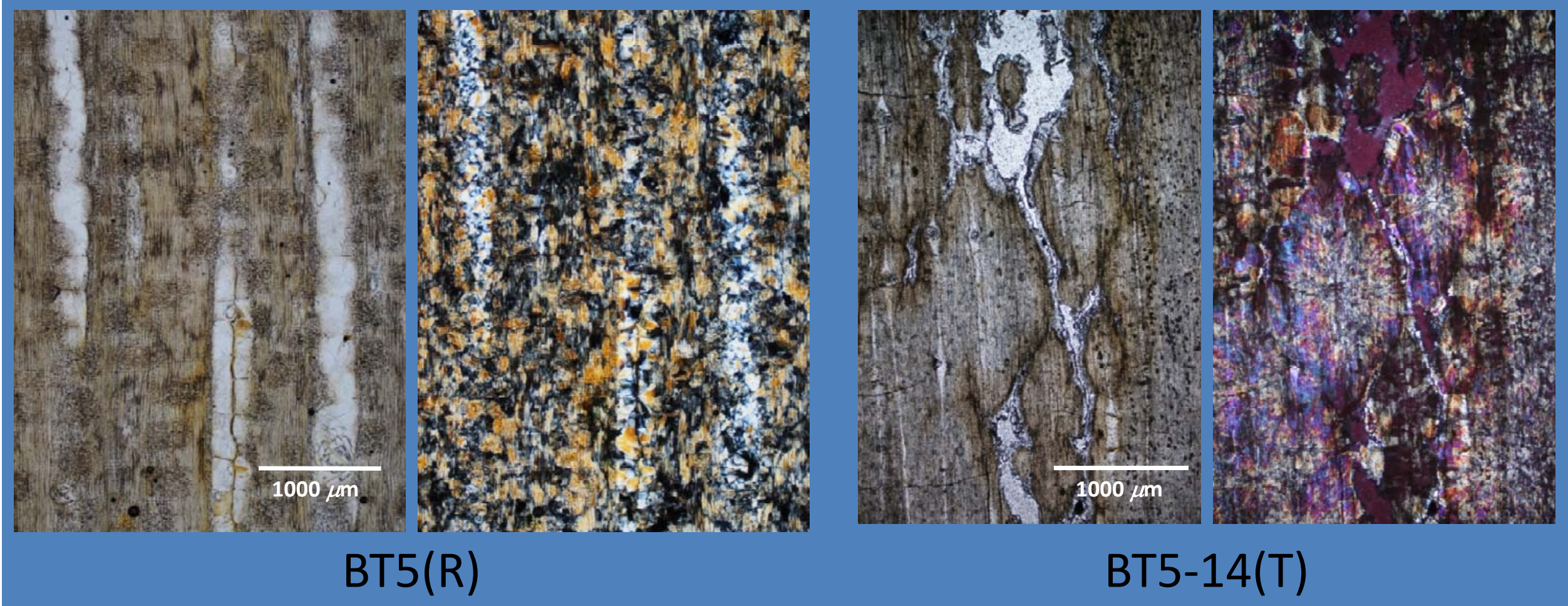

BT5-14(T) 


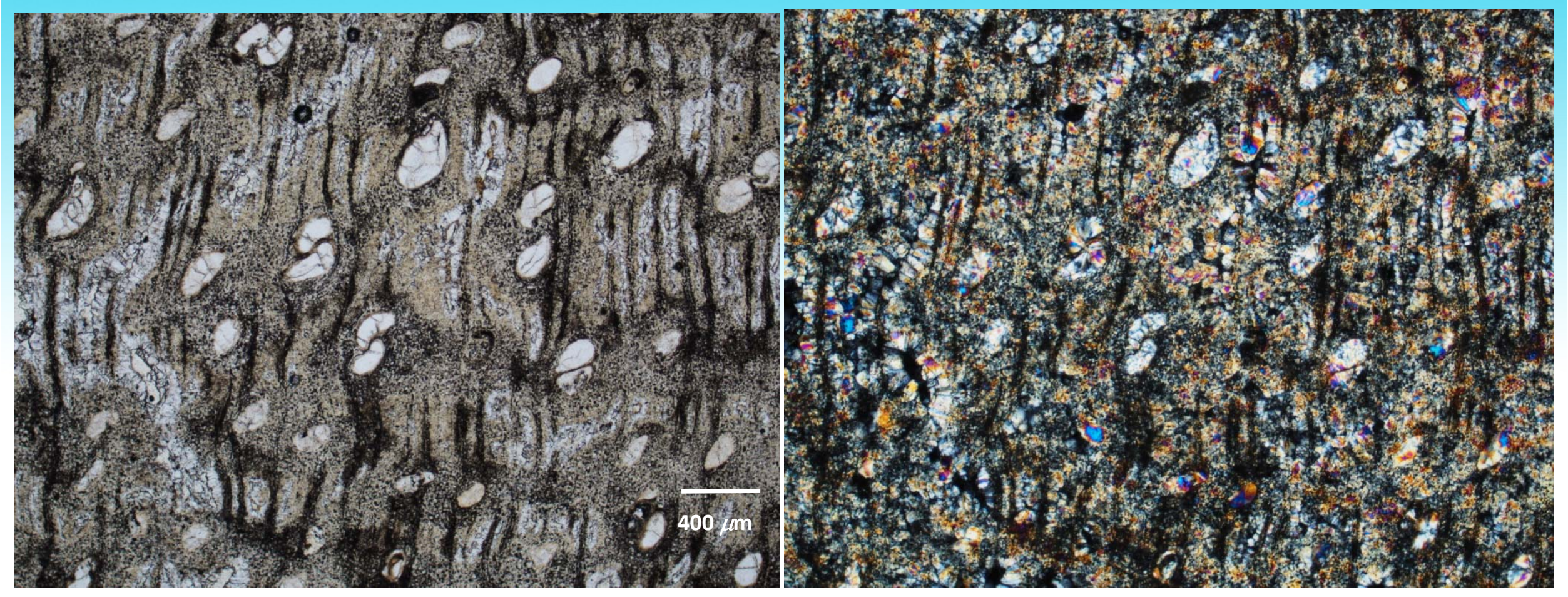

BT6(C)

\begin{tabular}{l|l} 
Srinakharinwirot University \\
Thailand
\end{tabular}

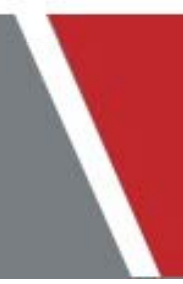




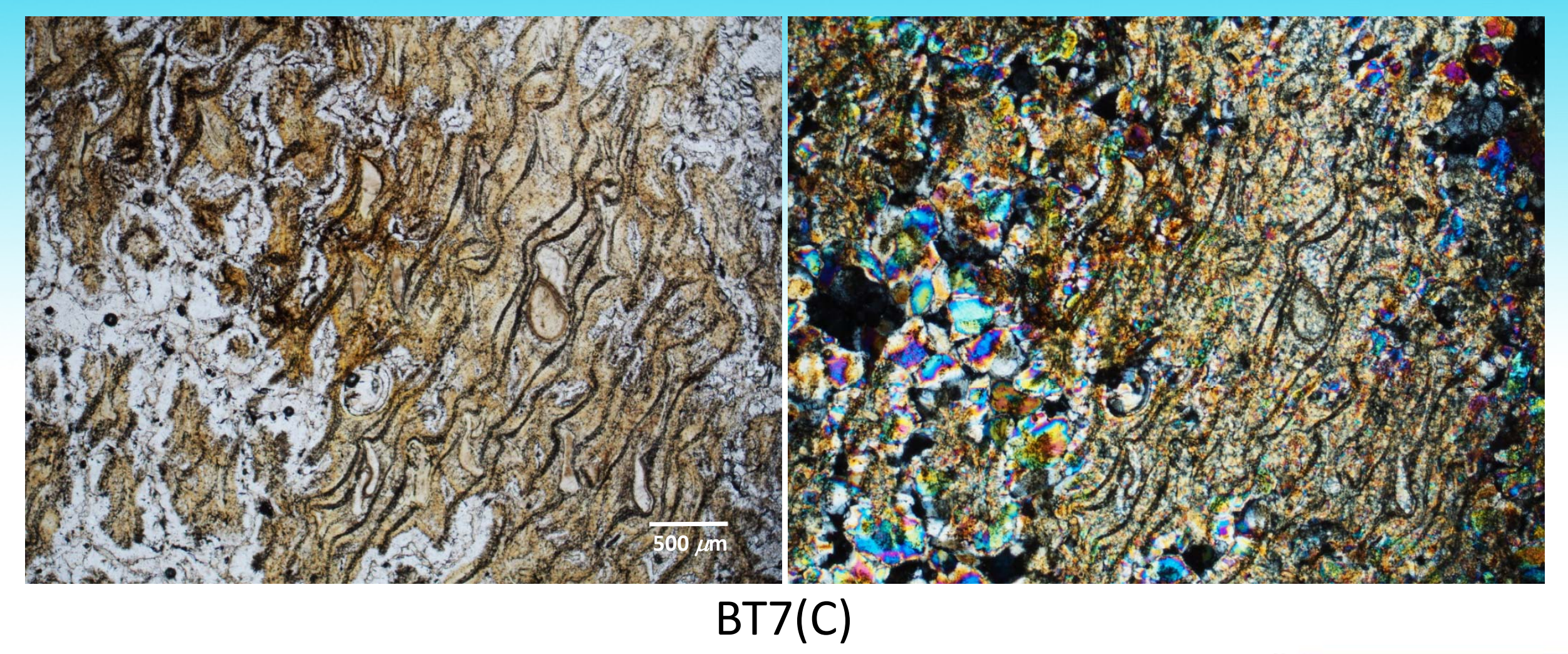

\begin{tabular}{l|l} 
Srinakharinwirot University \\
Thailand
\end{tabular}

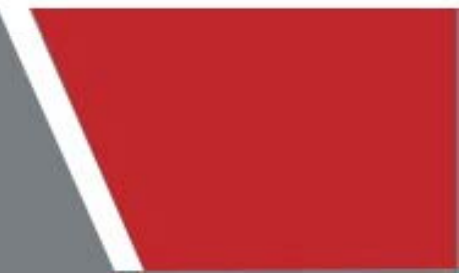




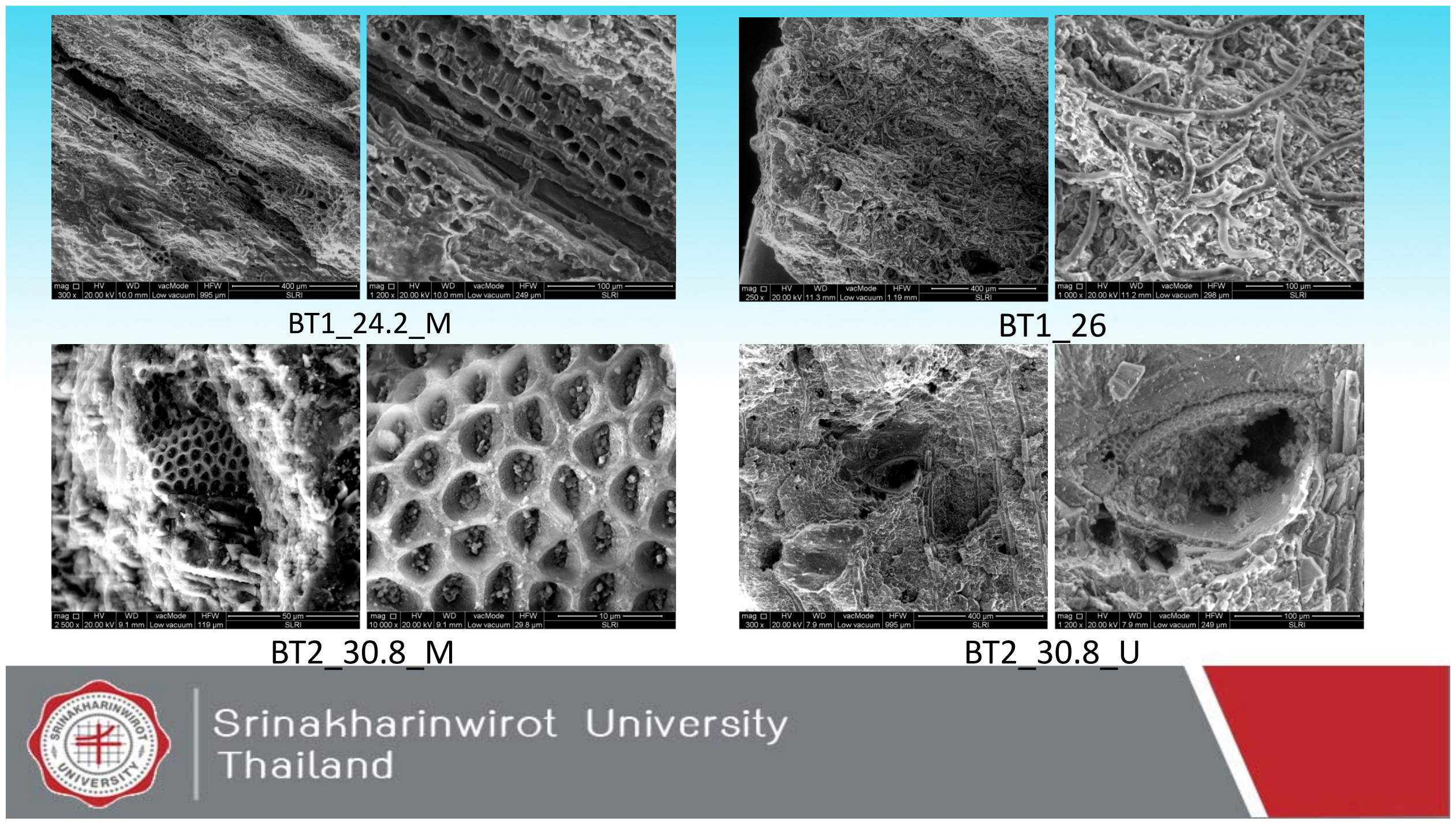




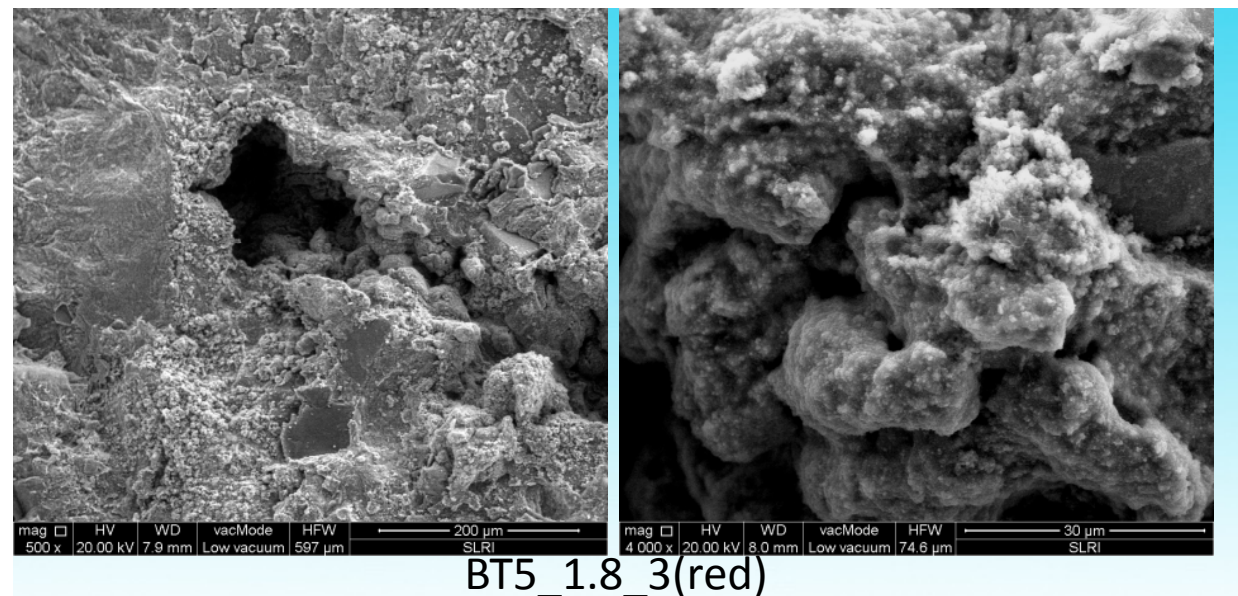

BT5_1.8_3(red)
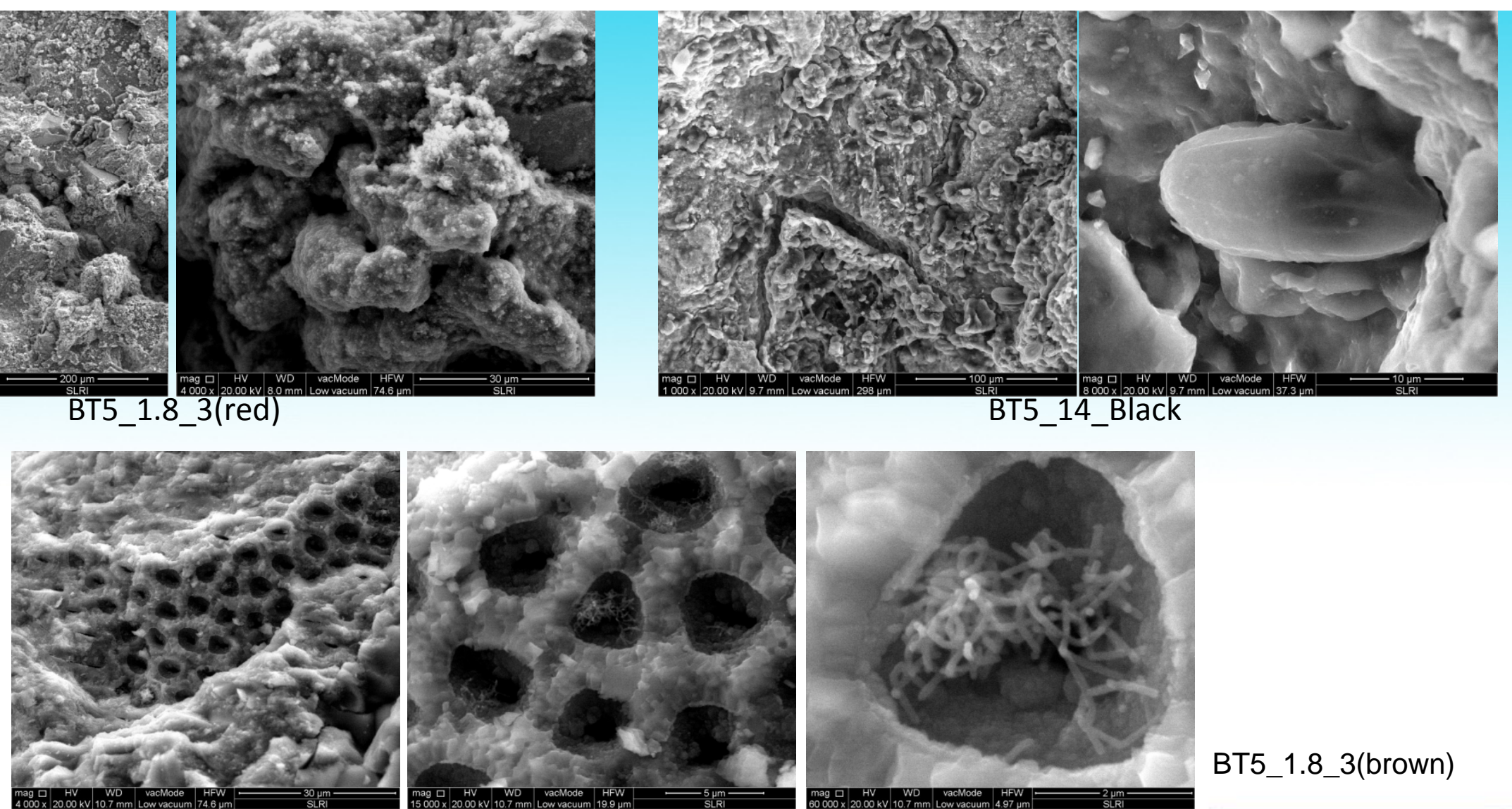

BT5_1.8_3(brown)

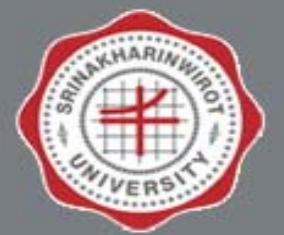

Srinakharinwirot University Thailand

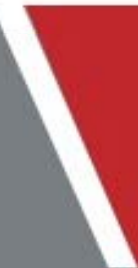




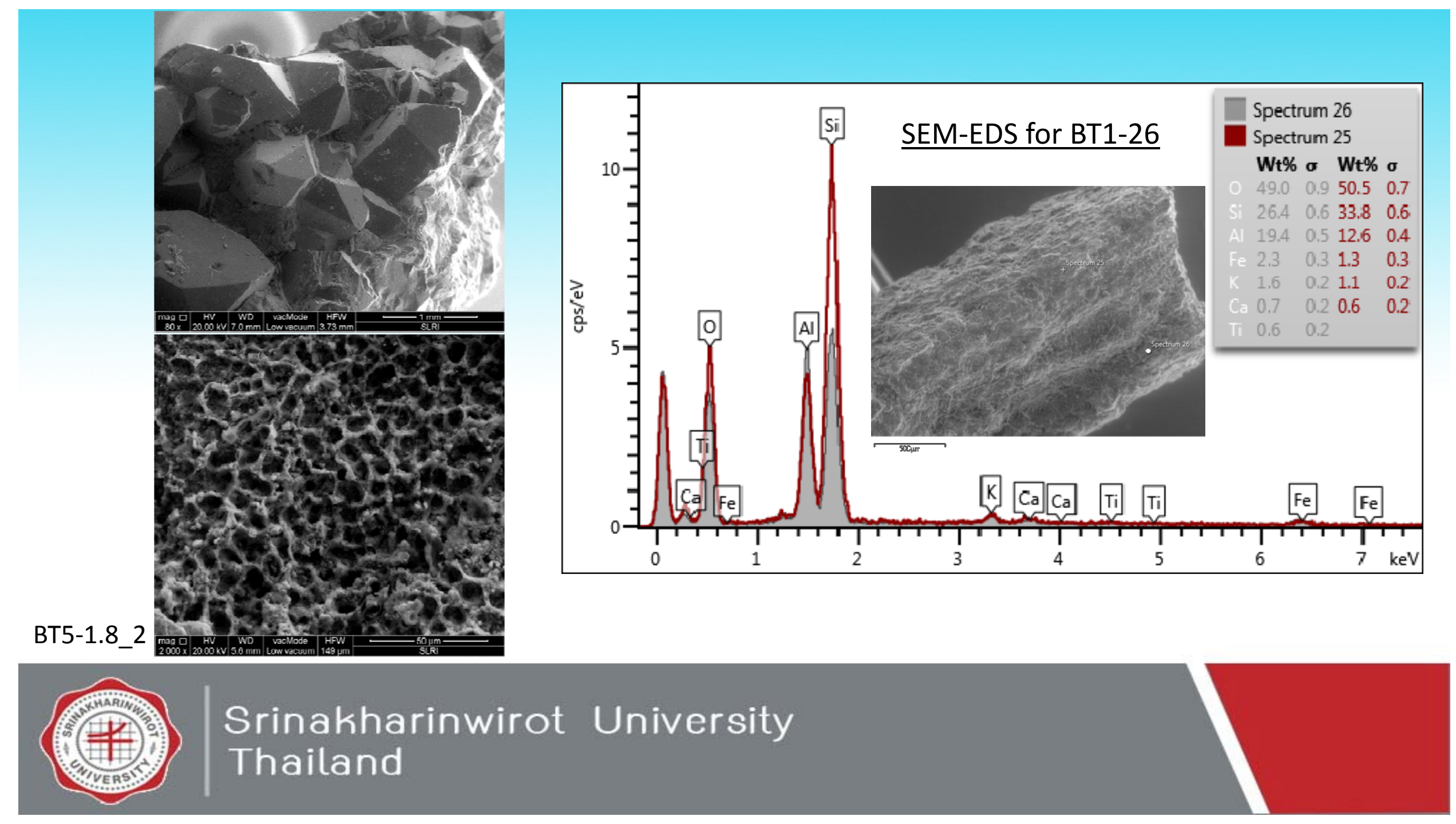



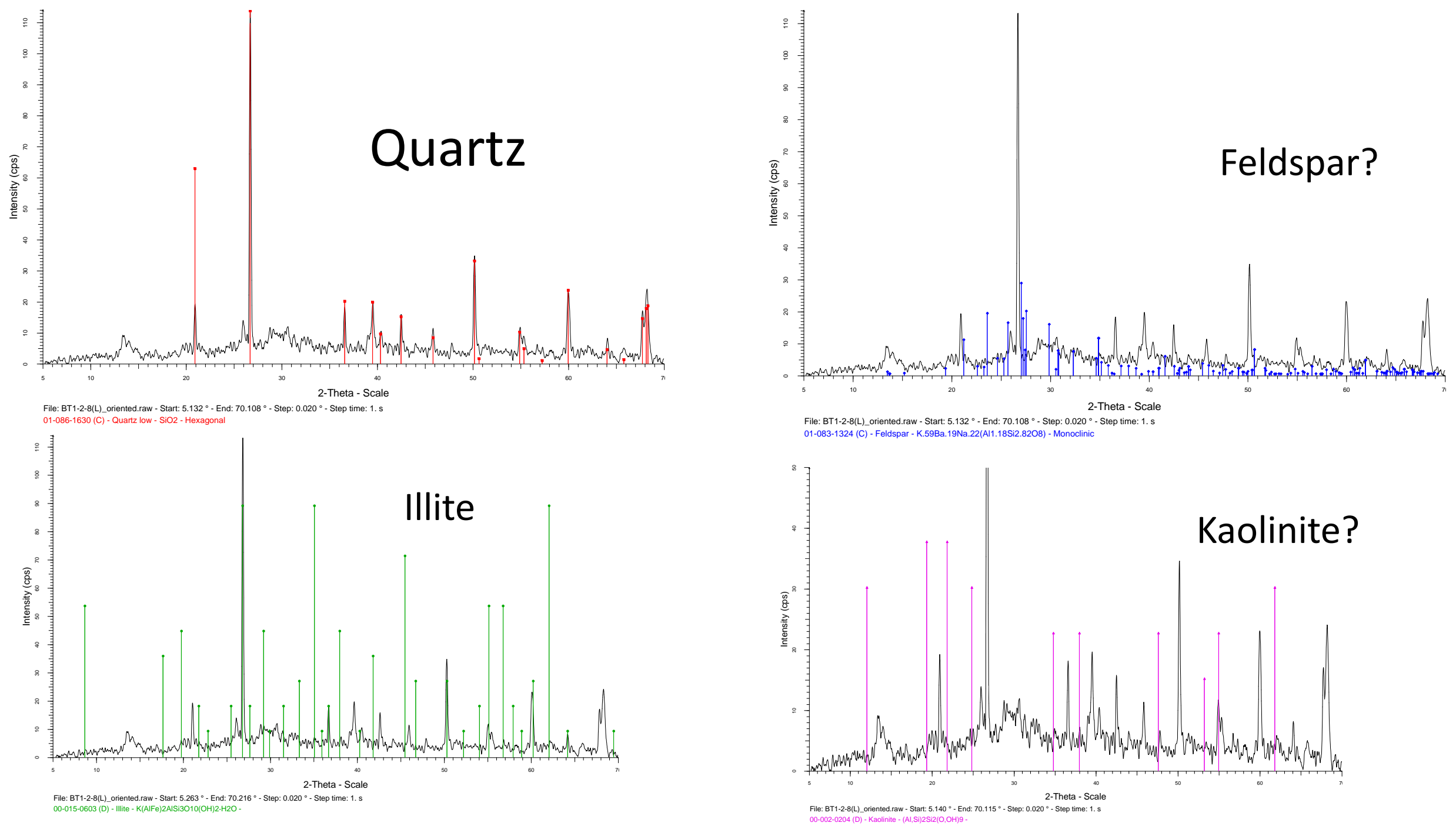


\section{Hematite?}

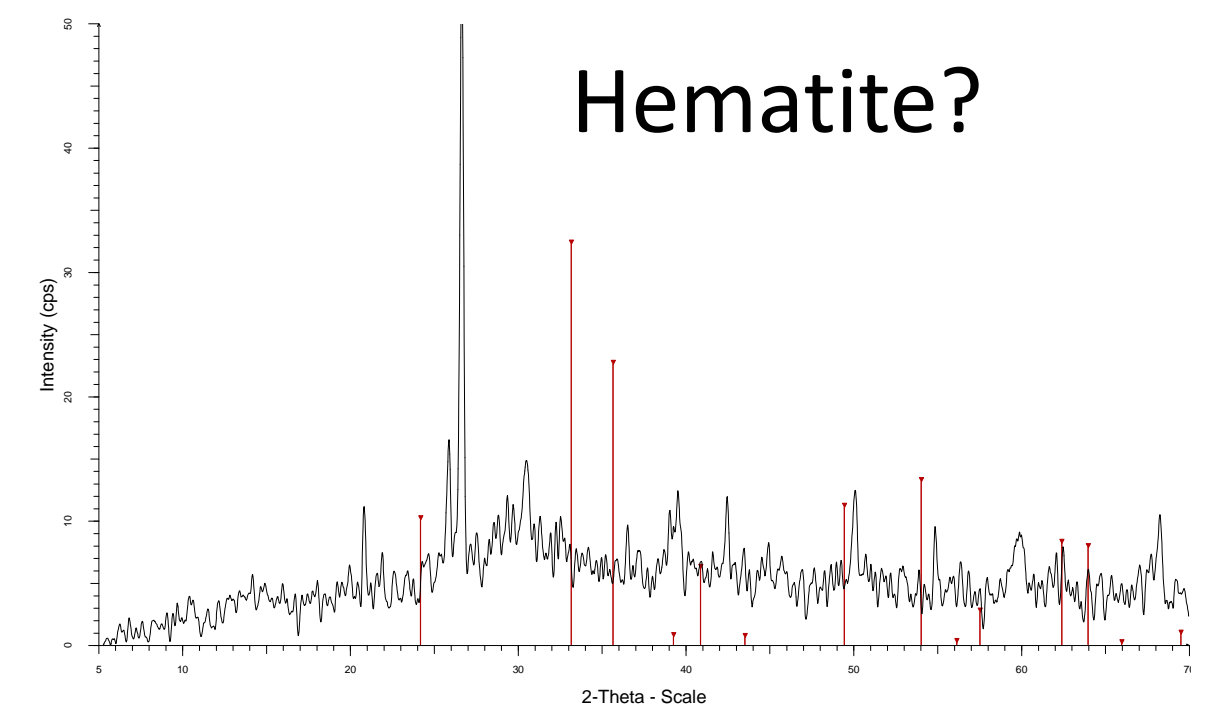

BT1-21.5C.spC A single scan measurement generated by the WiRE2 spectral acquisition wizard

File: BT1-11-97_oriented.raw - Start: $5.061^{\circ}$ - End: $70.050^{\circ}$ - Step: $0.020^{\circ}$ - Step time: 1 . s 01-072-0469 (C) - Hematite - Fe2O3 - Hexagonal (Rh)

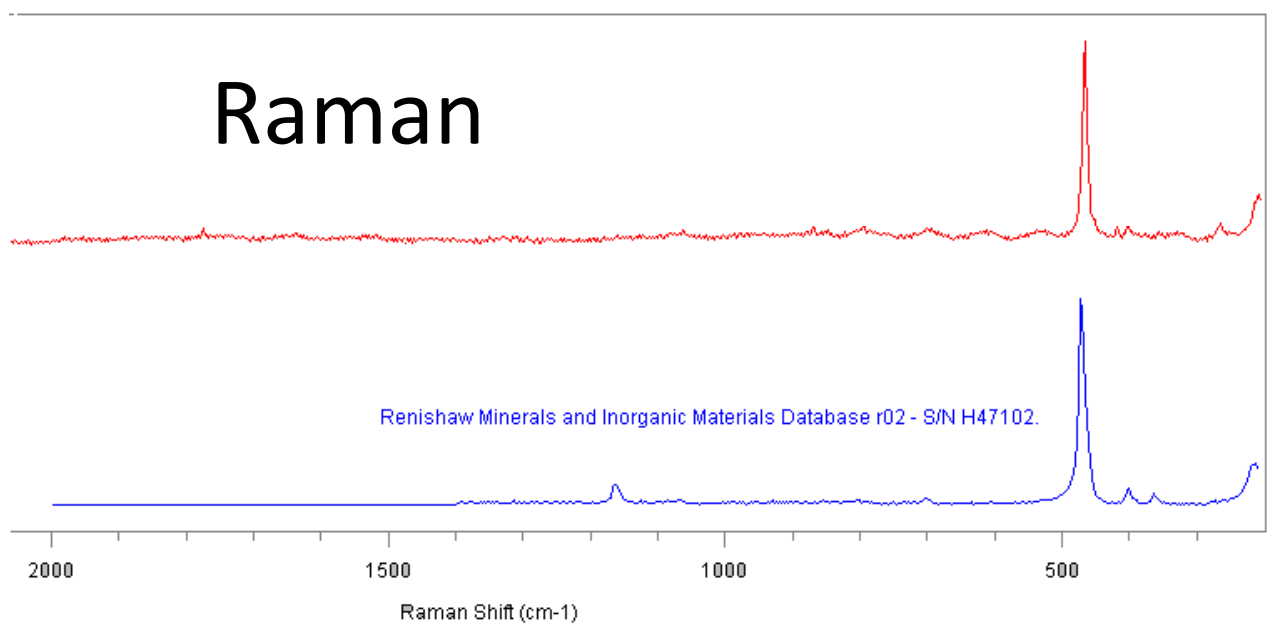




\section{Ages by Thermoluminescence, $\mathrm{TL}$}

BT6, age = 185,880+9,852 years

\section{BT7, age = 138,970+12,785 years}

(Won-in et al., 2018) 
- Quartz grains: Euhedral prismatic habit and granular habit.

\section{4) Summary of Results}

- Chalcedony in some samples (a spherulitic texture of fibrous quartz grains radiating from the vessel).

- The wood structures can be overgrown by the quartz.

- The weathered woods $\rightarrow$ show spongy appearance.

- Microorganism probably fungi is seen under the SEM.

- Fe-oxide compounds, red or reddish brown stains in other cells outside the vessels.

- Some samples $\rightarrow$ contortion cells, suggesting that the wood was subjected to a pressure after the deposition.

\section{2) SEM-EDS:}

$-\mathrm{O}, \mathrm{Si}$, and $\mathrm{Al} \rightarrow$ major elements

- $\mathrm{Fe}, \mathrm{K}, \mathrm{Ca}, \mathrm{Ti} \rightarrow$ trace elements

3) XRD and Raman $\rightarrow$ Quartz, illite, hematite?, kaolinite?, and feldspar?.

4) TL ages 130,000-180,000 years BP. 


\section{5) Discussion and Interpretation}

1) Silica solution penetrated to the wood structure then quartz crystallized.

2) The outer part of the vessel's cell wall has a larger area and higher resistant from the weathering than those of other cells. This provides a suitable area for prismatic quartz grains to grow in the divergent habit.

3) Other cells (e.g. ray, fiber, parenchyma), having their smaller structures which are perforated by the solution, and then they were overgrown by irregular/granular quartz grains.

4) The turbid inclusions seen in the grains are the impurities which their composition is not the same as the quartz $\left(\mathrm{SiO}_{2}\right)$ and they are still not identified at this stage.

\section{Srinakharinwirot University} Thailand 


\section{Thanks to:}

\section{ACKNOWLEDGEMENTS}

1) The National Science and Technology Development Agency (NSTDA), Thailand: project no. P-16-51513.

2) The National Geographic Society (NGS): grant no. CP-031R-17.

3) Srinakharinwirot University (SWU) for the travelling grant of presentation.

4) Collaborators: Nareerat Boonchai, Chiraporn Aranyanark, Suravech Suteethorn, Nirawat Thammajak, and staff of the Petrified Forest Park, Department of National Park (DNP), Wildlife and Plant Conservation, Thailand.

5) DNP, Royal Forest Dept. and Dept. of Mineral Resources, Thailand for issuing the Research permission documents.

6) Students (Tikamporn Amsamarng, Ratcha Limthong, Wanasanan Jatusan, and Nopporn Denkitkul) who helped on sample collection, preparation, and analyses.

7) Krit Won-in and staff, Thermoluminescence Laboratory, Kasetsart Univeresity.

8) Staff of the Synchrotron Light Research Institute (SLRI) for SEM-EDS analyses.

9) Staff of the Gem and Jewelry Institute of Thailand (GIT) for XRD analyses.

10) Mr. Pitthayuth Saminpanya for help on photography.

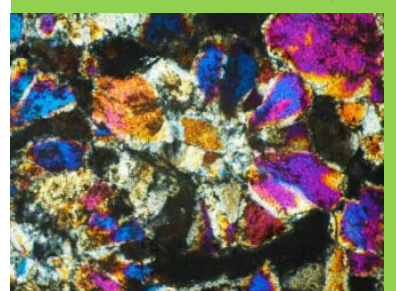

and

THANK YOU FOR YOUR ATTENTION.

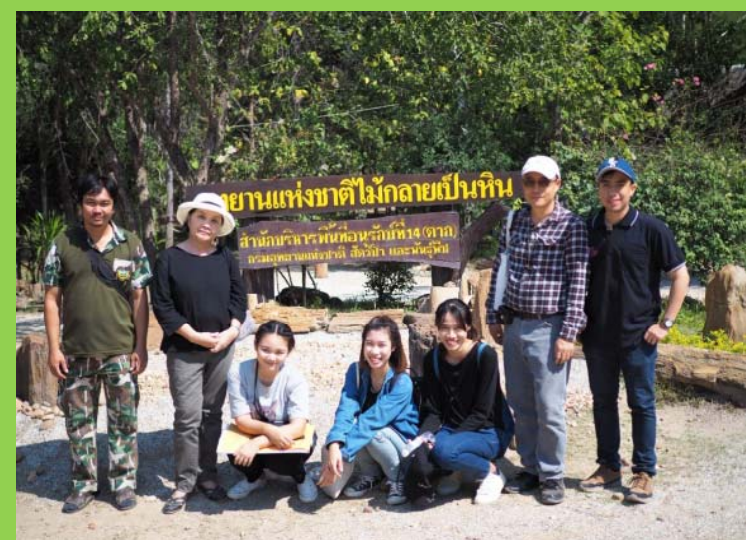

